\title{
Assessing internal and external controls on lake water quality: Limitations on organic carbon-driven alkalinity generation in acidic pit lakes
}

\author{
S. U. Salmon, ${ }^{1}$ C. E. Oldham, ${ }^{1}$ and G. N. Ivey ${ }^{1}$ \\ Received 8 February 2007; revised 30 April 2008; accepted 13 August 2008; published 21 October 2008.
}

[1] Organic carbon-driven alkalinity generation in acidic pit lakes may lead to amelioration of lake $\mathrm{pH}$. However, characterization of a pit lake $(\mathrm{pH} \mathrm{4-5)}$ with respect to temporal and spatial variation in state variables in the water column and inflows indicated that while the lake was a net sink for organic carbon, this carbon was either not being converted to alkalinity on a significant scale, or there were additional sources of acidity, possibly in the form of iron-rich groundwater. Internal organic carbon generation is limited by the availability of phosphorus; this limitation, together with internal carbon sinks, may be enhanced by the acidic conditions in the lake. This study has highlighted that well-constrained external mass balances, as well as assessment of integrated effects of internal geochemical, physical, and biological processes, are critical for forward prediction of water quality in pit lakes.

Citation: Salmon, S. U., C. E. Oldham, and G. N. Ivey (2008), Assessing internal and external controls on lake water quality: Limitations on organic carbon-driven alkalinity generation in acidic pit lakes, Water Resour. Res., 44, W10414, doi:10.1029/2007WR005959.

\section{Introduction}

[2] Acidic pit lakes have formed worldwide in voids resulting from mines for coal, gold, base metals, and uranium, among others [e.g., Miller et al., 1996; Eary, 1999]. There is increasing awareness of the importance of prediction of water quality evolution in pit lakes as a basis for managing long-term environmental, financial, and social impacts of mining. The acidity is generated by association of ore minerals with iron sulfide minerals, such as pyrite $\left(\mathrm{FeS}_{2}\right)$, which oxidize upon exposure to oxygen, resulting in the release of acidity in the form of dissolved $\mathrm{Fe}(\mathrm{II})$ and $\mathrm{H}+$ :

$$
2 \mathrm{FeS}_{2}+7 \mathrm{O}_{2}+2 \mathrm{H}_{2} \mathrm{O} \Rightarrow 2 \mathrm{Fe}^{2+}+4 \mathrm{SO}_{4}^{2-}+4 \mathrm{H}^{+}
$$

[3] Subsequent oxidation of $\mathrm{Fe}$ (II) to $\mathrm{Fe}$ (III) consumes protons, but precipitation of $\mathrm{Fe}$ (III) produces additional protons, e.g.:

$$
\mathrm{Fe}^{3+}+3 \mathrm{H}_{2} \mathrm{O} \Leftrightarrow \mathrm{Fe}(\mathrm{OH})_{3}(\mathrm{~s})+3 \mathrm{H}^{+}
$$

Aluminum, released by acid-enhanced weathering of minerals such as aluminosilicates, behaves in a similar manner to Fe(III) (equation (2)), and thus also contributes to acidity in solution. As a result of these and other reactions, pit lakes often exhibit high concentrations of acidity, sulfate, and metals; conditions of low $\mathrm{pH}$ lead to greater mobility and bioavailability of metals. Such water quality severely limits beneficial enduses of the site [e.g., Doupé and Lymbery, 2005] and may constitute an environmental hazard

\footnotetext{
${ }^{1}$ School of Environmental Systems Engineering, University of Western Australia, Nedlands, Western Australia, Australia.
}

Copyright 2008 by the American Geophysical Union. 0043-1397/08/2007WR005959\$09.00 both in the water body itself and for downstream environments and water resources [Miller et al., 1996; Geller et al., 1998].

[4] Alkalinity may be produced by naturally occurring microbially mediated processes, such as the reduction of $\mathrm{NO}_{3}^{-}, \mathrm{Fe}(\mathrm{III})$ and $\mathrm{SO}_{4}$, which occur under anaerobic conditions [e.g., Kelly et al., 1982]:

$$
\begin{gathered}
5 \mathrm{CH}_{2} \mathrm{O}+4 \mathrm{NO}_{3}^{-}+4 \mathrm{H}^{+} \Rightarrow 2 \mathrm{~N}_{2}+5 \mathrm{CO}_{2}+10 \mathrm{H}_{2} \mathrm{O} \\
\mathrm{CH}_{2} \mathrm{O}+4 \mathrm{FeOOH}+8 \mathrm{H}^{+} \Rightarrow 4 \mathrm{Fe}^{2+}+\mathrm{CO}_{2}+7 \mathrm{H}_{2} \mathrm{O} \\
2 \mathrm{CH}_{2} \mathrm{O}+\mathrm{SO}_{4}^{2-}+\mathrm{H}^{+} \Rightarrow \mathrm{HS}^{-}+2 \mathrm{CO}_{2}+2 \mathrm{H}_{2} \mathrm{O}
\end{gathered}
$$

(equations from Stumm and Morgan [1996]). If associated with degassing of reaction products or the precipitation of secondary iron sulfides, this internal alkalinity generation (IAG) has the potential to ameliorate water column acidity. However, laboratory and mesocosm experiments with sediments from acidic pit lakes have shown that the main factor limiting alkalinity generation is the availability of labile organic carbon, in either dissolved or particulate form [e.g., Wendt-Potthoff et al., 2002; Frömmichen et al., 2003, 2004; see also review in Blodau, 2006]. Therefore correctly conceptualizing and quantifying controls on sources and sinks of organic carbon in acidic pit lakes may be key for predicting whether acidic lakes will become more or less acidic with time, and furthermore, whether mitigation or remediation can be achieved without costly, long-term remediation measures, such as ongoing, large-scale chemical addition. 


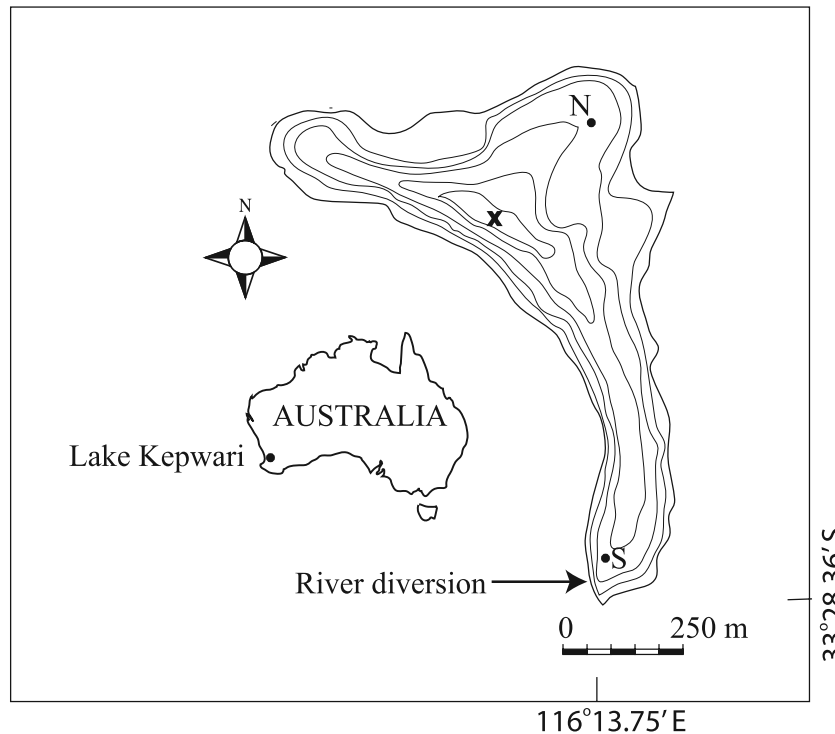

Figure 1. Bathymetric map of Lake Kepwari, showing $10 \mathrm{~m}$ depth contours and the location of the Lake Diagnostic System $(\times)$, the additional sampling sites ( $\mathrm{S}$ and $\mathrm{N})$, and the river inflow.

[5] Water quality in any lake is affected by the external water, mass, and energy balances, as well as internal processes, which may include: (1) physical processes, e.g., transport, mixing/stratification, exchange of gases with the atmosphere; (2) geochemical processes, e.g., aqueous speciation, mineral precipitation/dissolution, sorption, photochemical reactions; and (3) biological processes, e.g., primary production due to photosynthesis, microbially mediated mineralization of organic matter and associated redox reactions (e.g., equations (3)-(5)).

[6] A number of general overview papers exist on sources and sinks of acidity in and around pit lakes [Miller et al., 1996; Geller et al., 1998; Blodau, 2006] and numerous studies have characterized pit lakes with respect to physical limnology, geochemistry, biology, or sediment processes [e.g., Stevens et al., 2005; Davis and Ashenberg, 1989; Nixdorf et al., 1998; Wendt-Potthoff et al., 2002]. In addition, extensive literature exists describing interactions between acidity and sources and sinks of carbon and nutrients in the context of lakes acidified by atmospheric deposition and process engineering [e.g., Schindler et al., 1991, 1997; Kastl et al., 2004]. However, despite the close links between sinks and sources of organic carbon and geochemical and physical processes in the water column and sediment, the integrated effect of physical, chemical and biological controls on pit lake water quality evolution has rarely been considered. The overall aim of our study was thus to test our conceptual understanding, synthesized from highly disparate, scattered and interdisciplinary literature sources, of processes controlling the water quality evolution in acidic systems such as pit lakes.

[7] The Collie coal basin in south-west Western Australia has a number of acidic pit lakes in existence, including Lake Kepwari (formerly known as void WO5B; Figure 1). Since the cessation of mining in 1997 the lake has been rapidly filled in stages (Figure 2) via diversion of the adjacent Collie River South Branch, reaching the capacity volume of approx. 24 gigaliters (GL) in 2005. At the start of the field investigations described below in 2004, the $\mathrm{pH}$ in the lake had increased from a minimum of 3.6 to just below

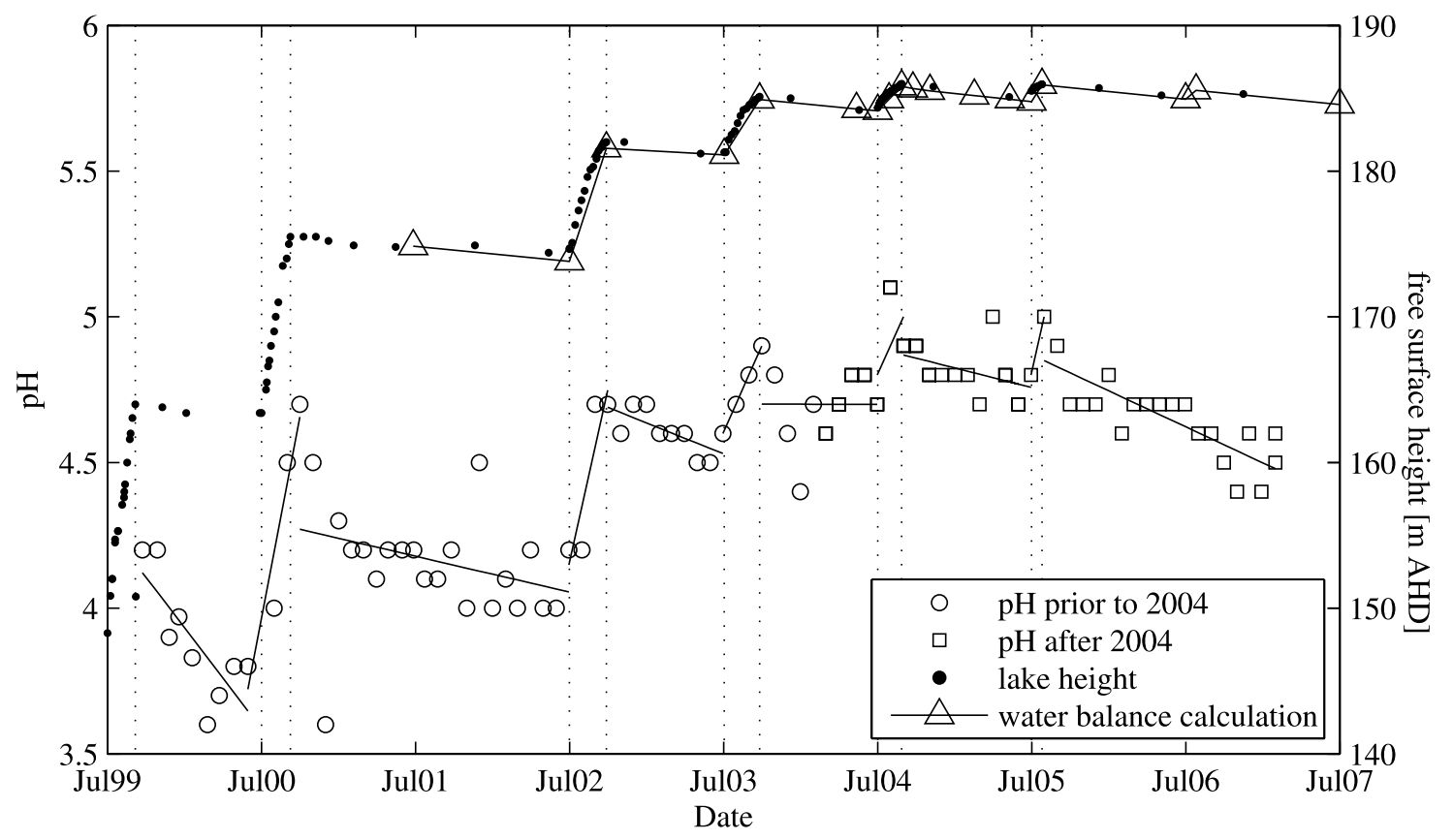

Figure 2. Changes in water level and $\mathrm{pH}$ in Lake Kepwari as the lake was filled by river diversion (source: Wesfarmers Premier Coal). Diversion periods are indicated by vertical dotted lines and are associated with increase in lake height and $\mathrm{pH}$; trendlines for $\mathrm{pH}$ indicate trends during or between diversion periods. Also shown are the results of the water balance calculation (see equation (7) and associated text). 
5 , which is the minimum value stipulated for recreational use of the lake. It was our objective to assess whether the acidity (or alkalinity) of the lake would increase or decrease with time; as became clear from the $\mathrm{pH}$ data collected after commencement of this study (Figure 2, squares), $\mathrm{pH}$ exhibited a downward trend from 2005 onward. This understanding of the controls on $\mathrm{pH}$ required geochemical characterization of the lake and its inflows, establishment of external mass balances, and formulation of a conceptual model of interactions between physical, chemical and biological lake processes.

\section{Methods}

\subsection{Site Description}

[8] Lake Kepwari, formerly known as Mine Lake WO5B, is a pit lake located in the Cardiff Sub-basin of the Collie Coal Basin, $160 \mathrm{~km}$ south-southeast of Perth, Western Australia (Figure 1). The region has a Mediterranean climate with hot, dry summers $\left(12\right.$ to $\left.29^{\circ} \mathrm{C}\right)$ and cool, wet winters (4 to $15^{\circ} \mathrm{C}$ ). The annual average wind speed at the center of the lake is around $3 \mathrm{~m} \mathrm{~s}^{-1}$, with peaks of up to $9 \mathrm{~m} \mathrm{~s}^{-1}$. The 100-year average annual rainfall for the Collie Basin is between 730 and $950 \mathrm{~mm}$, the majority of which occurs between May and September; however the annual rainfall for the past 10 years, monitored by the mining company, was approximately $600 \mathrm{~mm}$. The average annual potential evaporation is estimated to be between 1450 and $1650 \mathrm{~mm}$.

[9] The Collie Basin has a complex hydrogeology due to the prevalence of faults throughout the many geological formations, extensive underground and open cut mining, and the large volumes of groundwater abstraction, both historically and ongoing today [Varma, 2002]. Prior to mining of the Lake Kepwari pit, the largely unsaturated Cretaceous Nakina Formation, made up of claystone, sandstone and conglomerate, formed the surficial soils. This formation was extensively excavated to access the underlying Permian Muja Coal Measure, made up of sandstone, siltstone and numerous black, sub-bituminous coal seams [Varma, 2002]. Since the cessation of mining in the pit in 1997, the slopes and overburden piles surrounding the pit have been landscaped and revegetated; coal seams exposed during mining are covered and/or submerged.

[10] Dewatering of the WO5B pit ceased in 1997 and the void started to fill with groundwater and precipitation. By 1999 , the lake volume was approximately $1.2 \mathrm{GL}$, or $5 \%$ of the final lake capacity of approximately 24 GL. Between 1999 and 2005 the lake was rapidly filled by annual winter diversion of the adjacent ephemeral Collie River South Branch (Figure 2), with the exception of 2001, when flow in the river was insufficient for diversion. Inflow of the river, which was diverted around the void prior to mining, was through a valve that allowed control of inflow rates; overflow culverts limited the maximum height of the water level to approximately $186 \mathrm{~m}$ AHD (Australian Height Datum), above which the lake would overflow back into the river. The volume of the lake in 2001, when preliminary water quality samples were collected (see below), was approximately half the final volume. During the main field investigations described in this paper (2004-2005), the maximum depth of the lake was approximately $65 \mathrm{~m}$, and the lake surface area was approximately $1 \mathrm{~km}^{2}$.

\subsection{Field Measurements}

[11] A Lake Diagnostic System (LDS, Precision Measurement Engineering) was installed at the deepest point of the lake (Figure 1) from October 2003 to March 2006. The LDS measured wind speed, wind direction, air temperature, relative humidity and short wave and net radiation, at a sampling rate of 15 seconds. The LDS also recorded water column temperature via 20 thermistors over the $60 \mathrm{~m}$ water depth.

[12] Water column profiles of temperature, conductivity, dissolved oxygen (DO) and $\mathrm{pH}$, with depth resolutions ranging from $2 \mathrm{~cm}$ to $2 \mathrm{~m}$, were measured on 12 May, 28 July, 23 September, and 2 November 2004, and in 2005 on 15 February, 10 May, and 26 July. Profiles were made using a fine-scale conductivity-temperature-depth (CTD) profiler mounted with Seabird sensors until February 2005, after which a Hydrolab Datasonde 4a probe was used. On all occasions, 2-point calibration was performed on $\mathrm{pH}, \mathrm{DO}$ and conductivity sensors immediately prior to the field campaign. Conductivity was corrected to $25^{\circ} \mathrm{C}$ according to standard methods [APHA, 1992]. The density of samples from the lake was checked with an Anton Paar digital densitometer and, over the ranges of found in the lake, was found to be consistent with the density computed from the UNESCO Equation of State with a high degree of accuracy. Profiles were measured at multiple sites across the lake to characterize any horizontal heterogeneity. In-situ redox potential profiles were measured using a platinum electrode mounted on a probe (in May and July 2004, Yeokal 611; in May 2005, Hydrolab probe) and corrected to against the standard hydrogen electrode according to the manufacturers' instructions. Profiles of photosynthetically active radiation (PAR) were measured using a Licor LI-193SA underwater quantum sensor in May and July 2004 and May 2005, and light extinction coefficients were calculated. In situ profiles of fluorescence were measured on 15 February 2005 at the deepest part of the lake using a multispectral fluorometer (BBE Fluoroprobe).

\subsection{Sample Collection-Lake Water Column}

[13] Chemical profiles were collected on 12 May, 28 July, and 23 September 2004, and 15 February, 10 May, and 26 July 2005 . On each sampling trip, water samples were collected in duplicate from 4 to 7 depths at the deepest point of the lake, and in May and June 2004 also at 1-2 additional locations in the lake (locations $\mathrm{N}$ and S; Figure 1). Water samples were collected by hand from immediately below the surface and from depth using a van Dorn sampler, with separate drops for depth duplicates. Each water sample was transferred to a 1-L high-density polyethylene bottle (soaked in 10\% hydrochloric acid, repeatedly soaked in fresh deionized water and rinsed 3 times with sample water at the time of collection) that was filled to minimize airspace. The bottles were shielded from ambient light and kept as close as possible to constant temperature until sub-sampling and filtering (where necessary), which occurred on site or nearby, as soon as possible after collection (always within six hours).

[14] One subsample $(125 \mathrm{~mL})$ was filtered through $0.45 \mu \mathrm{m}$ cellulose acetate single use syringe filters into low-density polyethylene bottles; syringes and bottles were acid washed as described above. The filtered sample was 
acidified to $\mathrm{pH}<2$ using p.a. grade concentrated nitric acid, for later analysis by inductively coupled plasma-atomic emissions spectroscopy (ICP-AES; Varian Vista AX) of $\mathrm{Ca}, \mathrm{Mg}, \mathrm{Na}, \mathrm{K}, \mathrm{Al}, \mathrm{Fe}, \mathrm{Mn}, \mathrm{Zn}$, and $\mathrm{S}$ (and in May 2004 for $\mathrm{Ag}, \mathrm{As}, \mathrm{B}, \mathrm{Ba}, \mathrm{Cd}, \mathrm{Co}, \mathrm{Cr}, \mathrm{Cu}, \mathrm{Mo}, \mathrm{Ni}, \mathrm{Pb}, \mathrm{Sb}$, Se, Sn, $\mathrm{Sr}, \mathrm{Ti}$, and V). Additional subsamples $(10 \mathrm{~mL})$ were filtered into nutrient tubes for analysis of filterable reactive phosphorus (FRP), $\mathrm{NO}_{3}^{-}, \mathrm{NH}_{4}^{+}, \mathrm{SO}_{4}^{2-}, \mathrm{Cl}$ and $\mathrm{Si}$ (and in May 2004 for $\mathrm{F}$ and $\mathrm{Br}$ ) by colorimetry (Lachat Automated Flow Injection Analyzer). Additional unfiltered subsamples were set aside for total nitrogen (total N) and total phosphorus (total P) analysis, after persulfate and autoclave digestion. In May 2004 and July 2005, unfiltered water samples were also collected for ICP analysis of total (unfiltered) concentrations of major cations and sulfur, with sample acidification and aqua regia (mixture of hydrochloric and nitric acids) digestion prior to analysis. Samples were stored at $4^{\circ} \mathrm{C}$ or below until analysis.

[15] Water samples were collected for analysis of total and dissolved organic carbon (TOC/DOC) and dissolved inorganic carbon (DIC) from three depths in May 2004 and from all depths on the other sampling occasions. Amber glass bottles were rinsed 3 times with sample and filled to minimize airspace. These samples were stored on ice for analysis by combustion-non-dispersive infrared method (NDIR; Shimadzu Corporation TOC 5000A) after filtration as required. Discrete samples were also collected for chlorophyll $a$ analysis, using a benchtop fluorometer, from depths of 5 and $21 \mathrm{~m}$ in March and 5 and $10 \mathrm{~m}$ in July of 2004.

[16] In May 2005 additional water samples were collected from a number of depths for spectrophotometric analysis of $\mathrm{Fe}(\mathrm{II})$ and total Fe. Immediately after being brought to the lake surface, water samples were transferred into an acid washed syringe and $50 \mathrm{ml}$ was filtered through $0.45 \mu \mathrm{m}$ cellulose acetate filters into acid washed $125 \mathrm{ml}$ low-density polyethylene bottles that contained $2.5 \mathrm{ml}$ of p.a. grade $0.1 \mathrm{M} \mathrm{H}_{2} \mathrm{SO}_{4}$ and stored on ice until analysis (within eight hours). Immediately prior to analysis, samples were allowed to attain room temperature and returned to $\mathrm{pH} 3-5$ by

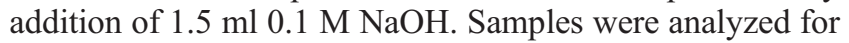
$\mathrm{Fe}(\mathrm{II})$ and total dissolved Fe using a HACH spectrophotometer (DR/2000); the concentration of total dissolved Fe analyzed by this method agreed well with analyses by ICP-AES on samples collected simultaneously by the method described above.

[17] Sampling, travel, and analytical blanks were collected and analyzed on all sampling occasions. Analyses of duplicate samples collected from the same depths generally showed agreement to within $10 \%$. The charge balance of cations and anions for all samples was generally within 5\%.

\subsection{Additional Water Samples}

[18] Water samples were collected in duplicate from the Collie River South Branch immediately adjacent to the diversion culvert on 9 occasions $(6,13,23,29$ June, 3 times on 20 July and twice on 21 July) during the 2004 river diversion into the lake. Surface runoff from the slopes surrounding the lake occurred only during rain events; replicate samples were collected during a rain event on 20 July 2004, one week prior to lake sampling. Samples were also collected in July 2001 from $1 \mathrm{~m}$ below the surface of the lake. The samples were processed by similar methods as described above, and analyzed for the same parameters as the water column samples.

\subsection{Acidity Calculations}

[19] The acidity of a solution is its capacity to neutralize $\mathrm{OH}^{-}$with respect to predefined reference species. Following the approach outlined in Blodau [2006], we define a reference condition, in this case a solution in equilibrium with the atmosphere at $\mathrm{pH} 5.6$; references species then include $\mathrm{Fe}(\mathrm{OH})_{3}(\mathrm{~s}), \mathrm{Al}(\mathrm{OH})_{3}(\mathrm{~s})$, and $\mathrm{H}_{2} \mathrm{CO}_{3}$. Acidity for relevant species in Lake Kepwari can then be calculated from:

$$
\begin{aligned}
\text { Acidity }= & 3\left[\mathrm{Fe}^{3+}\right]+2\left[\mathrm{Fe}(\mathrm{OH})_{2}^{+}\right]+\left[\mathrm{Fe}(\mathrm{OH})^{2+}\right] \\
& +3\left[\mathrm{Al}^{3+}\right]+2\left[\mathrm{Al}(\mathrm{OH})_{2}^{+}\right]+\left[\mathrm{Al}(\mathrm{OH})^{2+}\right] \\
& +2\left[\mathrm{Fe}^{2+}\right]+\left[\mathrm{H}^{+}\right]-\left[\mathrm{HCO}_{3}^{-}\right]
\end{aligned}
$$

where the square brackets indicate total dissolved concentration in mol $\mathrm{L}^{-1}$. This equation reflects that in order to increase the $\mathrm{pH}$ of an acidic, Al- and Fe-bearing solution, sufficient alkalinity needs to be added to remove free protons as well as precipitate $\mathrm{Fe}(\mathrm{III})$ and $\mathrm{Al}$ (see equation (2)), where $\mathrm{Fe}(\mathrm{III})$ is likely to precipitate first because of lower solubility at a given $\mathrm{pH}$ [see, e.g., Totsche et al., 2003; Kirby and Cravotta, 2005]. For the water column and other solutions used in the mass balance calculations described below, speciation was obtained by applying the geochemical equilibrium model PHREEQC [Parkhurst and Appelo, 1999] with thermodynamic data from the WATEQ4F database [Ball and Nordstrom, 1991]. The dominant Al species in the lake was $\mathrm{AlSO}_{4}^{+}$; this was assumed to have the same acidity contribution as $\mathrm{Al}^{3+}$. For acidity calculations all $\mathrm{Fe}$ in the water column was assumed to be Fe(III), which may lead to a slight error in calculation of acidity if iron is present as $\mathrm{Fe}(\mathrm{II})$ (see section 3 below); however, Fe was a minor component of the overall acidity in the water column. Note that $\mathrm{Fe}(\mathrm{II})$ is soluble over a much wider range of $\mathrm{pH}$ values than $\mathrm{Fe}(\mathrm{III})$; anoxic groundwater may thus have a high $\mathrm{pH}$ and high levels of acidity, because of Fe(II). Upon exposure to oxygen, oxidation of $\mathrm{Fe}$ (II) to $\mathrm{Fe}$ (III) and precipitation (equation (2)) will produce $\mathrm{H}^{+}$.

\subsection{Saturation Indices}

[20] In order to investigate the possibility of solubility equilibrium control of aqueous concentrations and $\mathrm{pH}$ in the lake, aqueous speciation and saturation indices were calculated using PHREEQC and the WATEQ4F database [Ball and Nordstrom, 1991], which also includes solubility constants for the solid phases discussed below in relation to solubility equilibrium. Additional thermodynamic data for the $\mathrm{Fe}(\mathrm{III})-\mathrm{SO}_{4}$ mineral schwertmannite was taken from $\mathrm{Yu}$ et al. [2002]. Total Fe and redox values were used as inputs to the modeling, as geochemical equilibrium calculations with PHREEQC indicated that this approach closely reproduced the Fe(II) concentrations measured in Lake Kepwari in May 2005 (see results and Figure 5 below), and redox potential and total $\mathrm{Fe}$ data were available for the other sampling occasions. As the concentrations of DOC in the lake were very low, and the specific complexing properties of the Lake Kepwari DOC not determined in this study, 
DOC complexation was not included in the saturation index calculations.

\subsection{Conservative Mass Balance Calculations}

[21] In order to establish a basis for interpreting temporal trends in lake water quality observations, we quantified the effect of known external processes through simple, conservative (not affected by reaction) mass balances over the lake. Comparison of calculations with field observations reveals whether changes in concentrations with time are due to the effect of inflows and/or evapoconcentration, or whether there are an additional sink or source term(s) in/ around the lake. For the $\mathrm{i}+1^{\text {th }}$ timestep, evolution of lake volume (V) was estimated according to:

$$
V_{i+1}=V_{i}+V_{r}+V_{p}+V_{g i}+V_{s r}-V_{e}-V_{g o}
$$

where $V_{i}$ is the lake volume at the end of the previous timestep, $\mathrm{V}_{\mathrm{r}}, \mathrm{V}_{\mathrm{p}}, \mathrm{V}_{\mathrm{gi}}$, and $\mathrm{V}_{\mathrm{sr}}$ are volumes gained over the timestep due to riverine diversion, precipitation, groundwater inflow, and surface runoff, respectively, and $V_{e}$ and $\mathrm{V}_{\mathrm{go}}$ are volumes lost due to evaporation and groundwater outflow, respectively.

[22] The mass of any component in the lake, M, on the $\mathrm{i}+1^{\text {th }}$ timestep, is given by:

$$
M_{i+1}=C_{i+1} V_{i+1}=C_{i} V_{i}+C_{r} V_{r}+C_{s r} V_{s r}+C_{g i} V_{g i}-C^{*} V_{g o}
$$

where $C_{i}$ is the solute concentration on the lake at the previous timestep, $\mathrm{C}_{\mathrm{r}}, \mathrm{C}_{\mathrm{sr}}$, and $\mathrm{C}_{\mathrm{gi}}$ are the solute concentrations in the river inflow, surface runoff, and groundwater inflow, respectively, and $\mathrm{C}^{*}$ is an approximate concentration in the void for the timestep. The solute concentration in each inflow was assumed to be constant for the timestep and evaporation and precipitation (see equation (7)) were assumed to not have any associated chemical mass flux. The $\mathrm{C}^{*}$ term was approximated with $\mathrm{C}_{\mathrm{i}+1}$, then equation (8) rearranged for $\mathrm{C}_{\mathrm{i}+1}$ :

$$
C_{i+1}=\frac{C_{i} V_{i}+C_{r} V_{r}+C_{s r} V_{s r}+C_{g i} V_{g i}}{V_{i+1}+V_{g o}}
$$

\subsection{Input Data-Volumes}

[23] For the water balance calculation, the result of which is shown in Figure 2, the following parameter values were used in equation (7).

\subsubsection{Groundwater Inflow and Outflow, $V_{g}$}

[24] The current volume of annual groundwater discharge or recharge to the lake was unknown. As a sensitivity analysis of the volume of groundwater inflow, we test two scenarios, $\mathrm{V}_{\mathrm{g}}\left(=\mathrm{V}_{\mathrm{gi}}=\mathrm{V}_{\mathrm{go}}\right)=0$ or $2.2 \mathrm{GL}$. The $2.2 \mathrm{GL}$ estimate is based on the groundwater input (at $17^{\circ} \mathrm{C}$ ) required to reproduce the hypolimnetic temperature measured in the lake using a hydrodynamic energy balance model (G. Wake, personal communication).

2.8.2. River Inflow, $V_{r}$

[25] Yearly diversion volumes, estimated from the specifications of the valve used for the river diversion, may have underestimated the volume of river water entering the lake, as when the river ran high there was "backflow" into the lake through the lake overflow culverts. For comparison with field data we thus calibrated $\mathrm{Vr}$ to match measured lake levels (2002, 6.5 GL; 2003, 2.4 GL; 2004, 1.7 GL; 2005, $1.1 \mathrm{GL} ; 2006,0.6 \mathrm{GL})$. For the forward water balance calculation from 2007 onward, the river was used to top up the void to the maximum height $(186 \mathrm{~m})$ each year after summer evaporation and potential groundwater recharge, without overflow; this required an input of $1.4 \mathrm{GL}$ of river water in 2007 and 1 GL each year after that. The river inflow was assumed to occur in the mid-winter month of July each year; the year was divided into two timesteps, one during the period of river inflow, and the other for the remainder of the year.

2.8.3. Surface Runoff Inflow, $V_{\mathbf{s r}}$

[26] The annual volume of surface runoff inflow was assumed to be $0.05 \mathrm{GL}$ year $^{-1}$ [Varma, 2002] and was assumed to occur during river inflow periods.

2.8.4. Total Precipitation, $V_{p}$

[27] During riverine inflow periods in 2004 and 2005, measured values of precipitation were used. For all other calculations, we used the average precipitation of $0.6 \mathrm{~m}$ year $^{-1}$, assuming $0.1 \mathrm{~m} \mathrm{month}^{-1}$ during river inflow and $0.045 \mathrm{~m} \mathrm{month}^{-1}$ otherwise.

2.8.5. Evaporation, $\mathrm{V}_{\mathrm{e}}$

[28] Evaporation was set to the regional average of $1.5 \mathrm{~m}$ year $^{-1}$.

\subsection{Input Concentrations}

[29] The concentration terms in equation (9) were estimated as detailed below (see Table 1 for numerical values). 2.9.1. Initial Lake Concentrations, $\mathbf{C}_{\mathbf{i}, 0}$

[30] The initial lake concentrations were taken as those measured in June 2001, at which time the lake was fully mixed.

2.9.2. Riverine Concentrations, $\mathrm{C}_{\mathbf{r}}$

[31] The river drains an agricultural catchment and flows only in the winter; while there are known temporal variations in dissolved concentrations, the main concentration spikes occur early in the wet season prior to river diversion. Continuously logged, temperature-corrected conductivity, measured downstream of the diversion point, correlated well with our discrete measurements of major ion concentrations at the diversion point, but poorly with minor ions, including nutrients. For all ions we thus approximated the river concentrations from the average of the discrete river sample analyses in 2004 (Table 1) and, as a first estimate, assumed constant solute concentrations throughout each diversion period and across years.

\subsubsection{Surface Runoff Concentrations, $\mathrm{C}_{\mathrm{sr}}$}

[32] These concentrations were estimated by averaging duplicate samples of surface runoff, collected from one location as the runoff entered the lake during a rain event in July 2004. The runoff quality may differ significantly around the lake due to heterogeneity in the overburden material, and/or with time due to flushing of seasonally accumulated weathering products from the overburden.

\subsubsection{Groundwater Concentrations, $\mathrm{C}_{\mathbf{g i}}$}

[33] Data for groundwater samples were only available from four locations and a limited number of sampling occasions. Furthermore, only a limited number of parameters were analyzed, and it is not known whether any of the samples collected were representative of the groundwater actually entering the lake. To give an indication of available 
Table 1. Concentrations in Lake Kepwari and Inflows

\begin{tabular}{|c|c|c|c|c|c|c|}
\hline & $\begin{array}{c}\text { Lake } \\
(\text { July 2004) }\end{array}$ & $\begin{array}{c}\text { Lake } \\
\text { (June 2001) }\end{array}$ & River (2004) $)^{\mathrm{b}}$ & $\begin{array}{c}\text { Surface } \\
\text { runoff (2004) }\end{array}$ & $\begin{array}{c}\text { Groundwater } \\
(1998-2007)^{\mathrm{c}}\end{array}$ & $\mathrm{C}_{\mathrm{g}, \mathrm{fit}}{ }^{\mathrm{d}}$ \\
\hline $\mathrm{Al}\left(\mathrm{mg} \mathrm{L}^{-1}\right)$ & $1.1 \pm 0.02$ & 4 & $0.06(0.03-0.1)$ & 1.55 & & \\
\hline Total Al $\left(\mathrm{mg} \mathrm{L}^{-1}\right)$ & $1.3 \pm 0.2$ & & & & & \\
\hline $\mathrm{Ca}\left(\mathrm{mg} \mathrm{L}^{-1}\right)$ & $28.2 \pm 0.4$ & 20 & $30.7(23-44)$ & 2.55 & $2.5-16$ & \\
\hline $\mathrm{Fe}^{\mathrm{e}}\left(\mathrm{mg} \mathrm{L}^{-1}\right)$ & $0.15 \pm 0.01$ & 0.3 & $0.31(0.26-0.51)$ & 0.04 & $<0.01-21.6$ & 5 \\
\hline Total Fe $\left(\mathrm{mg} \mathrm{L}^{-1}\right)$ & $0.3 \pm 0.1$ & & & & & \\
\hline $\mathrm{K}\left(\mathrm{mg} \mathrm{L}^{-1}\right)$ & $4.86 \pm 0.08$ & 5.3 & $3.6(3.2-5.5)$ & 0.96 & $10-12$ & \\
\hline $\mathrm{Mg}\left(\mathrm{mg} \mathrm{L}^{-1}\right)$ & $77.2 \pm 0.5$ & 59 & $83.1(61-120)$ & 3.85 & $18-63$ & \\
\hline $\operatorname{Mn}\left(\mathrm{mg} \mathrm{L}^{-1}\right)$ & $0.211 \pm 0.002$ & 0.25 & $0.08(0.05-0.21)$ & 0.09 & $<0.01-0.4$ & \\
\hline $\mathrm{Na}\left(\mathrm{mg} \mathrm{L}^{-1}\right)$ & $329 \pm 2$ & 255 & $392(290-560)$ & 5.4 & $45-470$ & \\
\hline $\mathrm{Zn}\left(\mathrm{mg} \mathrm{L}^{-1}\right)$ & $0.468 \pm 0.005$ & 0.96 & $0.006(0.002-0.009)$ & 0.16 & & \\
\hline $\mathrm{Si}\left(\mu \mathrm{g} \mathrm{Si} \mathrm{L}{ }^{-1}\right)$ & $3870 \pm 700$ & 3552 & $3011(2400-4900)$ & 270 & & \\
\hline $\mathrm{Cl}\left(\mathrm{mg} \mathrm{L}^{-1}\right)$ & $769 \pm 7$ & 550 & $879(670-1300)$ & 0 & $64-860$ & 670 \\
\hline $\mathrm{SO}_{4}{ }^{2-}\left(\mathrm{mg} \mathrm{L}^{-1}\right)$ & $107 \pm 4.2$ & 120 & $60.5(47-89)$ & 35 & $16-72$ & 100 \\
\hline $\mathrm{NH}_{4}^{+}\left(\mu \mathrm{g} \mathrm{N} \mathrm{L}^{-1}\right)$ & $239 \pm 5$ & 500 & $30.9(15-82)$ & 135 & & \\
\hline $\mathrm{NO}_{3}^{-}\left(\mu \mathrm{g} \mathrm{N} \mathrm{L}^{-1}\right)$ & $972 \pm 9$ & 1500 & $811(430-1300)$ & 21 & $<1-4$ & 0 \\
\hline Total $\mathrm{N}\left(\mu \mathrm{g} \mathrm{N} \mathrm{L}^{-1}\right)$ & $1370 \pm 60$ & 1900 & $1710(1300-2200)$ & 1700 & & \\
\hline FRP $\left(\mu \mathrm{g} \mathrm{P} \mathrm{L} \mathrm{L}^{-1}\right)$ & $<2$ & 6 & $3.7(2-8)$ & $<2$ & $<10-100$ & \\
\hline Total $\mathrm{P}\left(\mu \mathrm{g} \mathrm{P} \mathrm{L}^{-1}\right)$ & $7.0 \pm 1.6$ & 6 & $21.7(17-31)$ & 255 & & \\
\hline TOC $\left(\mathrm{mg} \mathrm{C} \mathrm{L}^{-1}\right)$ & $2.1 \pm 0.1$ & 1 & $13.9(13-15)$ & 4.2 & & \\
\hline $\mathrm{DOC}\left(\mathrm{mg} \mathrm{C} \mathrm{L}^{-1}\right)$ & $1.9 \pm 0.1$ & 1 & $13.8(13-15)$ & & & \\
\hline $\mathrm{DIC}\left(\mathrm{mg} \mathrm{C} \mathrm{L}^{-1}\right)$ & $<0.5$ & & $7.2(5.9-10)$ & 0 & $<0.2-7.9$ & \\
\hline $\mathrm{pH}$ & 4.9 & 4.4 & $6.7(6.5-6.9)$ & 3.6 & $4.1-7.5$ & \\
\hline $\operatorname{Acidity}^{\mathrm{f}}(\mathrm{mM})$ & 0.14 & 0.5 & -0.6 & 0.42 & $-0.65-0.8^{\mathrm{g}}$ & 0.6 \\
\hline
\end{tabular}

${ }^{a}$ Average concentration \pm standard deviation of all samples from 28 July 2004 (see text), with the exception of total $\mathrm{Al}$ and total $\mathrm{Fe}$, which are the average of 2 single samples from 0 and $49 \mathrm{~m}$ at the LDS. Total P is the average of samples from locations $\mathrm{S}$ and $\mathrm{N}$ only, as all samples at the LDS were below the detection limit $\left(5 \mu \mathrm{g} \mathrm{P} \mathrm{L}^{-1}\right)$.

${ }^{\mathrm{b}}$ Average concentrations in all river samples, with range given as (min-max).

${ }^{c}$ Range (min-max) of analyses of groundwater samples collected at 2 locations in 1998 (one depth and one sampling occasion [Varma, 2002]), and at 2 locations on multiple sampling occasions from 1997 to 2007 (3 depths; source: Wesfarmers Premier Coal).

${ }^{\mathrm{d}}$ Groundwater concentration required to match field data observations in mass balance calculations; see text.

${ }^{\mathrm{e}}$ Total dissolved concentration.

${ }^{\mathrm{f}}$ Calculated using equation (6).

${ }^{\mathrm{g}}$ Possible underestimation of acidity, as $\mathrm{Al}$ was not analyzed. All Fe assumed to be in reduced form, Fe(II).

data, Table 1 shows the range of concentrations observed. Note that of the species that contributed to acidity, $\mathrm{pH}$ and $\mathrm{Fe}$ concentrations varied greatly, and $\mathrm{Al}$ has not been measured in any groundwater samples. Similarly, DOC and trace elements have not been measured.

[34] As $\mathrm{C}_{\mathrm{g}}$ was thus essentially an unknown, for those species where the mass balance groundwater scenario with $\mathrm{V}_{\mathrm{g}}=2.2 \mathrm{GL}$ and $\mathrm{C}_{\mathrm{g}}=0$ underestimated the field observations, we increased $C_{g}$ to match the field observations, then compared this value $\left(\mathrm{C}_{\mathrm{g}, \mathrm{fit}}\right)$ with the range of values observed in the groundwater analyses.

\section{Results}

\subsection{Field Measurements}

[35] In both 2004 and 2005, thermal stratification in the lake began in late September, peaked in February (maximum surface temperatures of $25^{\circ} \mathrm{C}$ ) and began breaking down in May (Figure 3), although stratification was still in place at the time of sampling in both years (Figure 4a). By June the lake was fully mixed and remained isothermal over the winter months; the minimum water temperature was $13^{\circ} \mathrm{C}$. Note that the river diversion occurred when the lake was isothermal.

[36] On all sampling occasions there was little horizontal variability in temperature, conductivity, $\mathrm{pH}, \mathrm{DO}$ or redox potential (not shown). In both years, by the end of the summer, the conductivity was higher in the epilimnion than in the hypolimnion, probably due to evapoconcentration of the surface waters (Figure 4b). The $\mathrm{pH}$ in the lake was between 4.5 and 5, with no clear temporal trend over the 2004-2005 period of investigation (Figure 4c).

[37] Dissolved oxygen concentrations were close to saturation in the upper waters of the lake on all sampling occasions (Figure 4d). Undersaturation was generally observed in the hypolimnion during stratified periods, however supersaturation was observed just below the thermocline in February 2005, presumably a signature of a deep photosynthesizing layer. This was supported by the observation in February 2005 of a deep chlorophyll maximum $\left(0.2 \mu \mathrm{g} \mathrm{L}^{-1}\right)$ located between $18-32 \mathrm{~m}$, with values at other depths otherwise under the detection limit (Figure 4e). Chlorophyll $a$ concentrations were highest in discrete samples in July 2004 , at $2-4 \mu \mathrm{g} \mathrm{L}^{-1}$; at all other times, concentrations were $<1 \mu \mathrm{g} \mathrm{L}^{-1}$. Light levels varied across seasons; extinction coefficients ranged from 0.2 to $0.7 \mathrm{~m}^{-1}$, indicating photic depths of $22 \mathrm{~m}$ and $6 \mathrm{~m}$ in May and July, respectively. The higher July chlorophyll $a$ concentrations indicated higher biomass, which may have caused the shallower photic depths observed at that time. However, the lower photic depth during the winter may also be due to fine inorganic particles, as substantial transport of particulate matter from the surrounding slopes into the lake was observed during the sampled rain event. Note the maximum chlorophyll $a$ concentrations measured in this lake were very low relative to most aquatic systems [Wetzel, 2001]. 


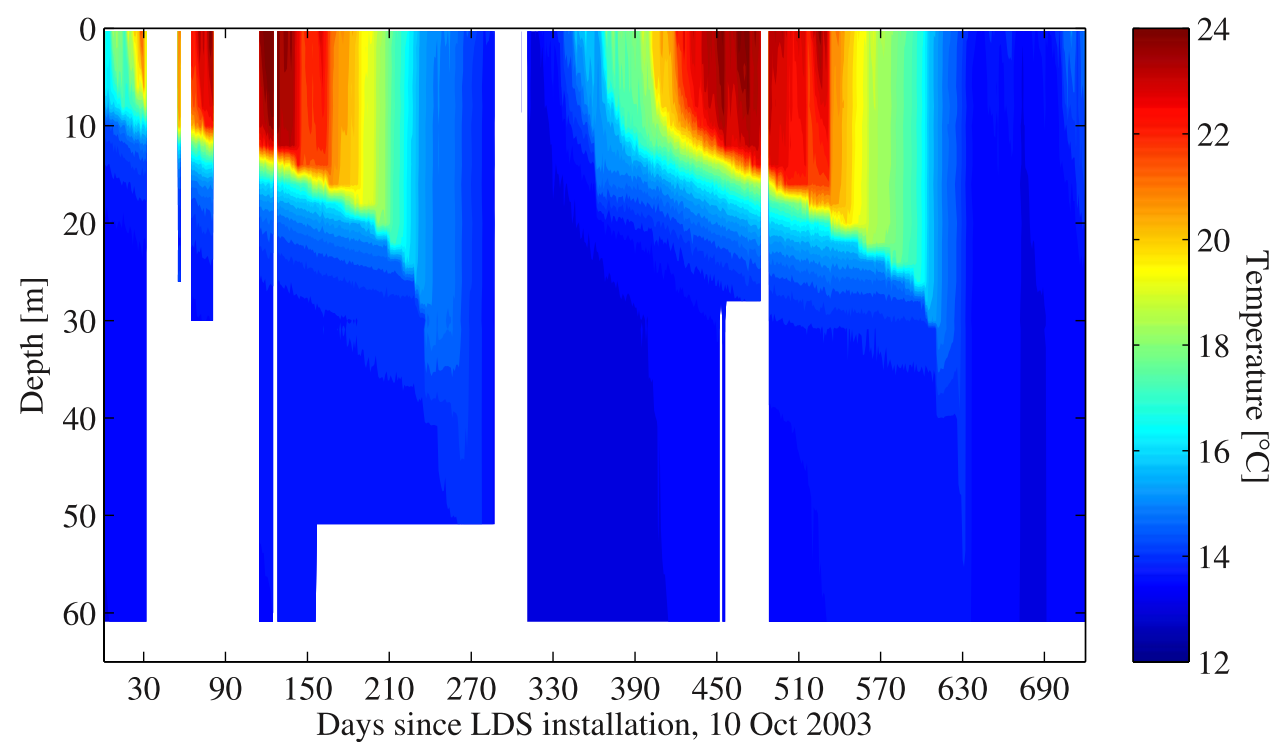

Figure 3. Temperature in Lake Kepwari measured by the LDS. Gaps in the data set are due to sensor malfunction, possibly due to lightning strikes.

During periods of stratification (May 2004 and May 2005) the redox potential increased with depth below the thermocline (Figure 4f).

\subsection{Aqueous Geochemistry}

[38] Depth averaged solute concentrations for all major species in the lake in July 2004, when the lake was well mixed, are presented in Table 1. The major dissolved ions were $\mathrm{Cl}$ and $\mathrm{Na}$, followed by $\mathrm{SO}_{4}^{2-}, \mathrm{Mg}$, and $\mathrm{Ca}$. Concentrations of elements analyzed but not shown in Table 1 were low or below the detection limit, and therefore unlikely to play a major role in controlling the water quality in the lake. Total concentrations of most major inorganic elements were the same as dissolved concentrations (not shown), with the exception of slightly higher total $\mathrm{Fe}$ and $\mathrm{Al}$ concentrations on some sampling occasions (Table 1). Note that measure-
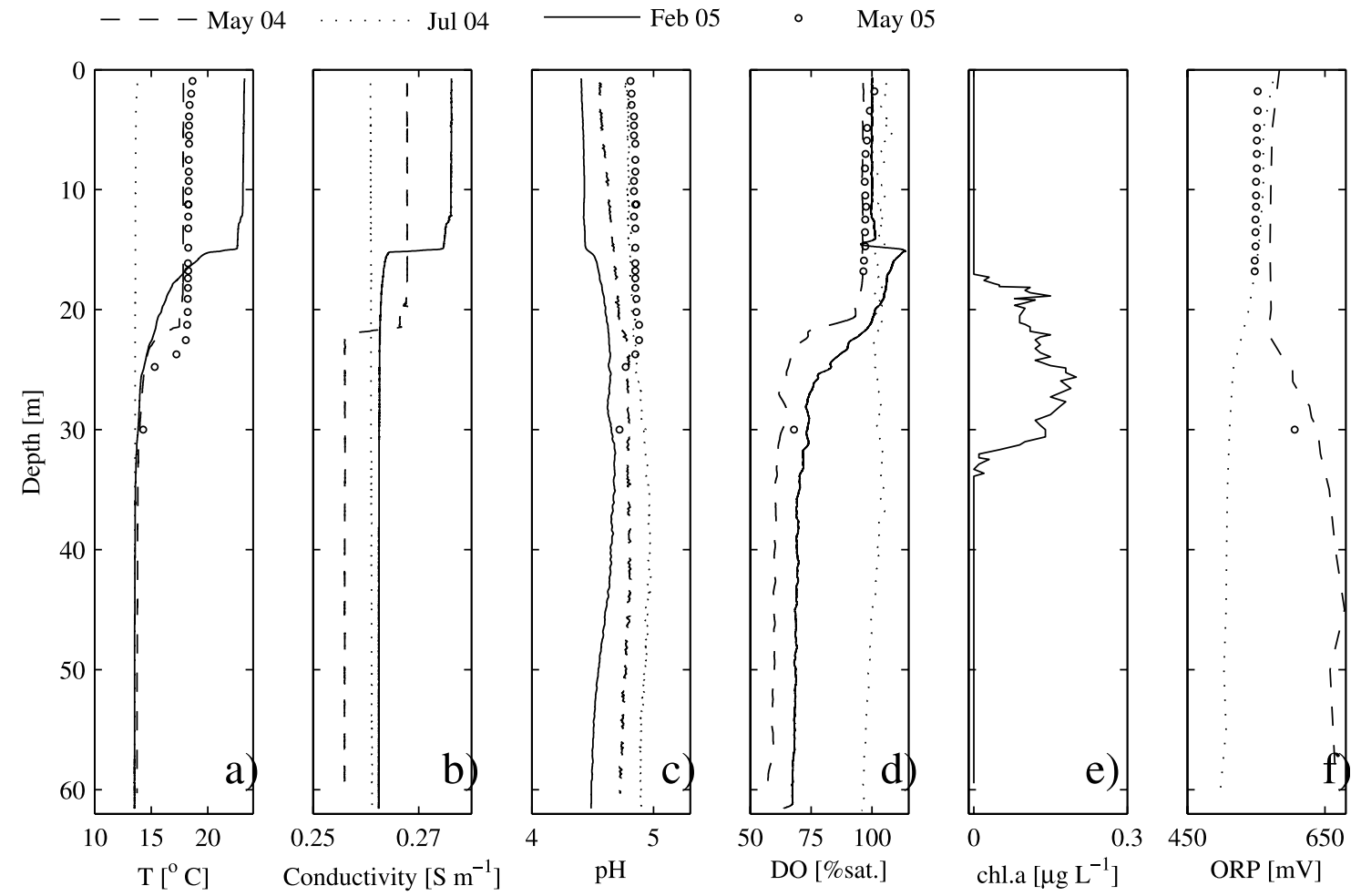

Figure 4. Water column profiles of (a) temperature, (b) conductivity, (c) pH, (d) dissolved oxygen, (e) chlorophyll $a$, and (f) oxidation-reduction (redox) potential (ORP), measured at the LDS site on one or more of 12 May 2004, 28 July 2004, 15 February 2005, and 10 May 2005. 
ment of solid phases by the difference between total and dissolved concentrations with such synoptic sampling is unlikely to capture mineral precipitation and sedimentation out of the water column.

[39] Concentrations of major anions $\mathrm{Cl}$ and $\mathrm{SO}_{4}^{2-}$ (Figures $5 \mathrm{a}-5 \mathrm{c}$ ) exhibited low horizontal variability and little variation with depth. However, during periods of stratification, slightly higher concentrations were observed in the epilimnion, as was consistent with the conductivity profiles and was attributed to evapoconcentration. Similar profiles were observed for $\mathrm{Ca}, \mathrm{K}, \mathrm{Mg}, \mathrm{Mn}, \mathrm{Zn}$, and $\mathrm{Si}$ (not shown), which indicated largely conservative seasonal behavior of these species. From May 2004 to May 2005, $\mathrm{Cl}$ concentrations increased slightly in the epilimnion and hypolimnion, whereas $\mathrm{SO}_{4}^{2-}$ concentrations decreased slightly.

[40] During periods of stratification, the ratio between dissolved $\mathrm{Fe}$ concentrations in the epilimnion and in the oxic hypolimnion was greater than what would be expected if evapoconcentration were the only factor (compare Figures $5 \mathrm{~d}$ and $5 \mathrm{f}$ with $\mathrm{Cl}$ profiles in Figures $5 \mathrm{a}$ and $5 \mathrm{c}$ ). The depth profile of $\mathrm{Al}$, on the other hand, did not display higher concentrations in the epilimnion during stratified conditions. Neither Fe nor Al showed clear temporal trends. Acidity was calculated to be $0.14 \mathrm{mM}$, the majority of which was due to $\mathrm{Al}$ species.

[41] The Fe(II) concentration profile in May 2005 (Figure 5f) indicated that $\mathrm{Fe}$ (II) was $30-40 \%$ of the total dissolved Fe. Geochemical speciation calculations using total dissolved $\mathrm{Fe}$ concentrations and the in-situ redox potential in PHREEQC reproduced the measured Fe(II) concentration, which suggested that the redox potential measurements made in May 2004 and July 2004 could also be used to predict the Fe redox speciation on those occasions, as has previously been demonstrated in other acidic systems [Nordstrom et al., 1979; Nordstrom and Alpers, 1999; Davis and Ashenberg, 1989; Pellicori et al., 2005].

[42] Saturation index (SI) values of $0 \pm 0.5$ indicate that precipitation/dissolution of specified mineral phases are likely to control the related aqueous species [Drever, 1997]. SI calculations indicated that precipitation/dissolution of amorphous $\mathrm{Fe}$ hydroxide $\left(\mathrm{Fe}(\mathrm{OH})_{3}(\mathrm{am})\right)$ was probably controlling $\mathrm{Fe}(\mathrm{III})$ concentrations at all depths $(-0.5<\mathrm{SI}<$ 0.3 ). Aluminum concentrations were possibly controlled by precipitation/dissolution of a hydroxysulfate $\left(\mathrm{AlOHSO}_{4}\right.$, $-0.6<\mathrm{SI}<-0.4)$ or hydroxide $\left(\mathrm{Al}(\mathrm{OH})_{3}(\mathrm{cr}), 0.2<\mathrm{SI}<\right.$ $0.9)$ phase. Solution was undersaturated with respect to other phases such as halite $(\mathrm{NaCl})$, or phases such as gypsum $\left(\mathrm{CaSO}_{4} \cdot 2 \mathrm{H}_{2} \mathrm{O}\right)$ that are commonly reported to control aqueous concentrations in mine lakes and other waters affected by acid mine drainage [e.g., Eary, 1999; Nordstrom and Alpers, 1999].

[43] Concentrations of all species, including those that exhibited non-conservative behavior during stratification, were constant with depth during non-stratified periods (e.g., Figures $5 \mathrm{~b}$ and $5 \mathrm{e}$ ).

\subsection{Carbon and Nutrients}

[44] Total N and TOC were composed predominantly of dissolved forms (Table 1). During periods of stratification, $\mathrm{NO}_{3}^{-}$concentrations displayed conservative depth behavior (Figures $6 \mathrm{a}$ and $6 \mathrm{c}$ ), with higher concentrations in the epilimnion, however concentrations decreased with time. In contrast, ammonium displayed elevated concentrations below the thermocline (Figures $6 \mathrm{a}$ and $6 \mathrm{c}$ ). At the $\mathrm{pH}$ and temperature measured in the lake, the DIC concentration in equilibrium with the atmospheric partial pressure of $\mathrm{CO}_{2}$ is below the analytical detection limit $\left(0.5 \mathrm{mg} \mathrm{C} \mathrm{L}^{-1}\right)$; measurements confirmed that the concentration of DIC was below detection limit in the epilimnion when the lake was stratified and throughout the water column when the lake was fully mixed, however, the DIC concentration in the hypolimnion reached up to $1.5 \mathrm{mg} \mathrm{C} \mathrm{L}^{-1}$ (Figures $6 \mathrm{~d}$ and $6 \mathrm{f}$ ). The concentration of organic carbon was higher in the hypolimnion than in the epilimnion during stratified periods (Figures 6d and 6f). Total $\mathrm{P}$ and FRP concentrations were close to or below detection limits $\left(5-10 \mu \mathrm{g} \mathrm{P} \mathrm{L} \mathrm{P}^{-1}\right.$ and $2 \mu \mathrm{g} \mathrm{P} \mathrm{L}{ }^{-1}$, respectively) on most sampling occasions (not shown).

[45] Concentrations of all species were constant with depth during non-stratified periods (e.g., Figures $6 \mathrm{~b}$ and 6e).

\subsection{Inflows}

[46] During the river diversion period in 2004, the $\mathrm{pH}$ of the Collie River South Branch, as measured on 9 occasions, varied from 6.5-7, and DIC concentrations ranged from 6.2 to $7.9 \mathrm{mg} \mathrm{C} \mathrm{L}^{-1}$. Concentrations of the major inorganic ions were similar in the lake and river (Table 1), which is consistent with $95 \%$ of the volume of the lake originally being river water.

[47] The sample of surface water runoff collected during a rain event in July 2004 was fairly dilute relative to the lake water, however, concentrations of dissolved $\mathrm{Al}$ and total $\mathrm{Al}$, Fe and $\mathrm{P}$ were high, and $\mathrm{pH}$ was much lower at 3.5 (Table 1).

\subsection{Data and Mass Balance Calculations}

[48] Comparison of the 2004-2005 lake data and the lake sample collected in 2001 (Table 1 and Figure 7) showed that concentrations of $\mathrm{Cl}$ and most major base cations increased over the intervening period, whereas $\mathrm{SO}_{4}^{2-}, \mathrm{Al}, \mathrm{Fe}$, acidity, and most nitrogen and phosphorus species decreased, and organic carbon concentrations remained approximately constant. Mass balance calculations were utilized to investigate whether differences in trends between species could be explained solely by inflows and evapoconcentration, or whether additional sinks and sources were affecting concentrations. A conservative mass balance for chloride reproduced the evolution of the lake concentrations relatively well, whether assuming (1) no groundwater inflow $\left(\mathrm{V}_{\mathrm{g}}=0\right)$ or (2) $2.2 \mathrm{GL}$ groundwater throughflow with groundwater concentrations $\left(\mathrm{C}_{\mathrm{g} \text {,fit }}\right.$, Table 1 , Column 6$)$ within the range of values observed in groundwater analyses (Table 1, Column 5). Both scenarios indicated that the jump in $\mathrm{Cl}$ concentration in 2002 was due to river inflow, and the

Figure 5. Water column concentration profiles of $(\mathrm{a}-\mathrm{c}) \mathrm{Cl}$ and $\mathrm{SO}_{4}{ }^{2-}$ and $(\mathrm{d}-\mathrm{f}) \mathrm{Al}$ and Fe in May 2004, July 2004, and May 2005. Sampling locations are given in Figure 1. The dashed lines indicate the extent of the thermocline during stratification periods. Figure 5f also shows measured and predicted Fe(II) concentrations in May 2005 (see text). 


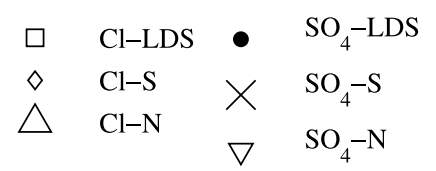

$\mathrm{SO}_{4}\left[\mathrm{mg} \mathrm{L}^{-1}\right]$
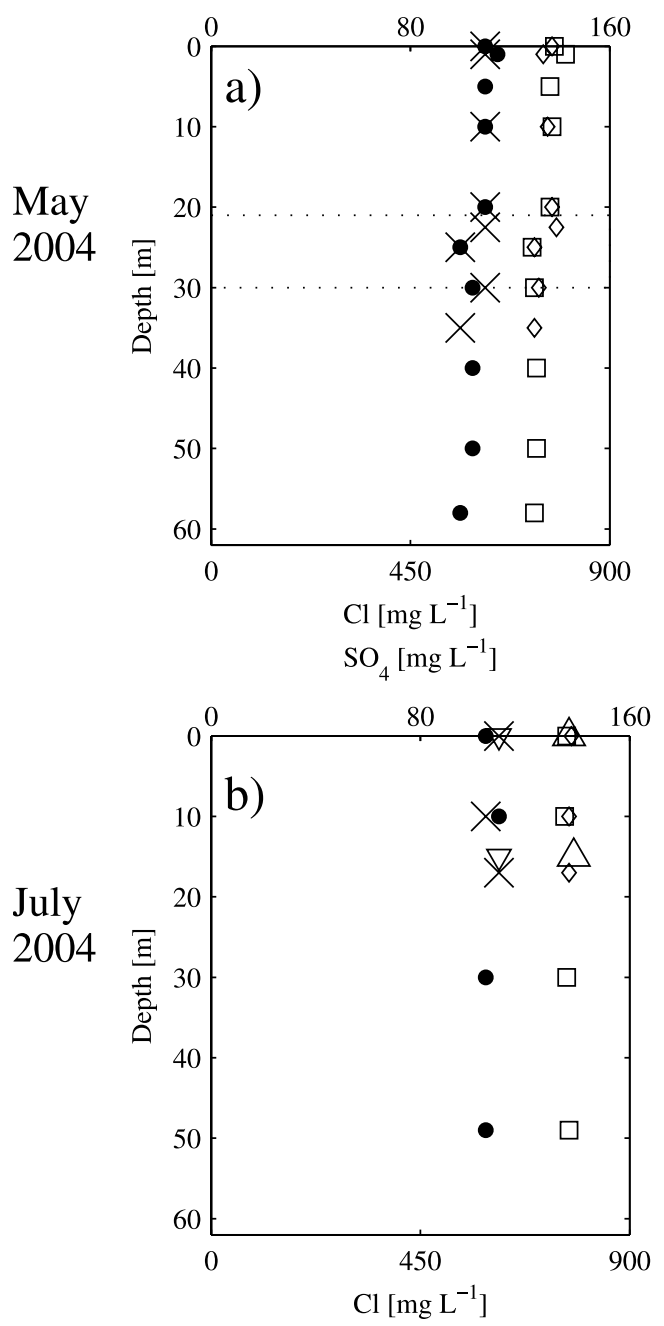

$$
\mathrm{SO}_{4}\left[\mathrm{mg} \mathrm{L}^{-1}\right]
$$

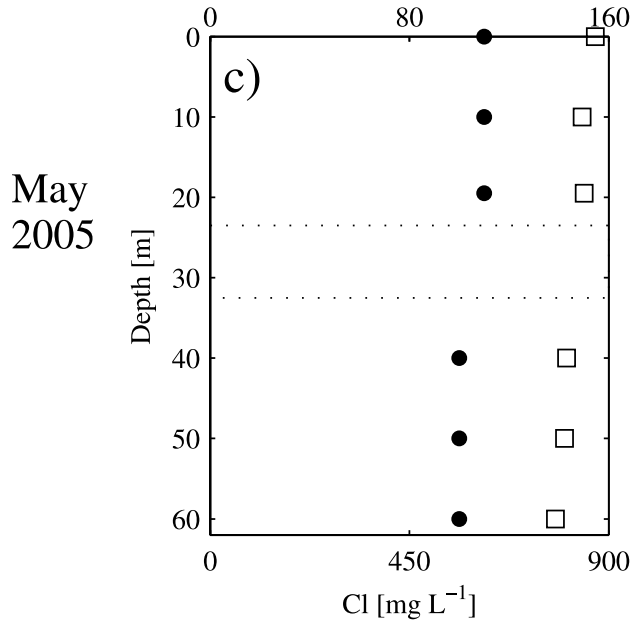

$\square \quad$ Al-LDS $\quad \bullet \quad \mathrm{Fe}-\mathrm{LDS}$

$\begin{array}{llll}\diamond & \mathrm{Al}-\mathrm{S} & X & \mathrm{Fe}-\mathrm{S} \\ \triangle & \mathrm{Al}-\mathrm{N} & \nabla & \mathrm{Fe}-\mathrm{N}\end{array}$

* $\quad \mathrm{Fe}(\mathrm{II})-$ meas $\mathrm{Fe}\left[\mathrm{mg} \mathrm{L}^{-1}\right] \quad \triangleright \quad \mathrm{Fe}(\mathrm{II})$-pred

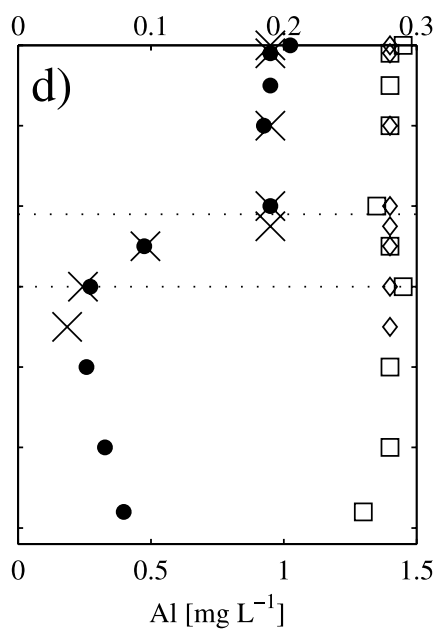

$\mathrm{Fe}\left[\mathrm{mg} \mathrm{L}^{-1}\right]$

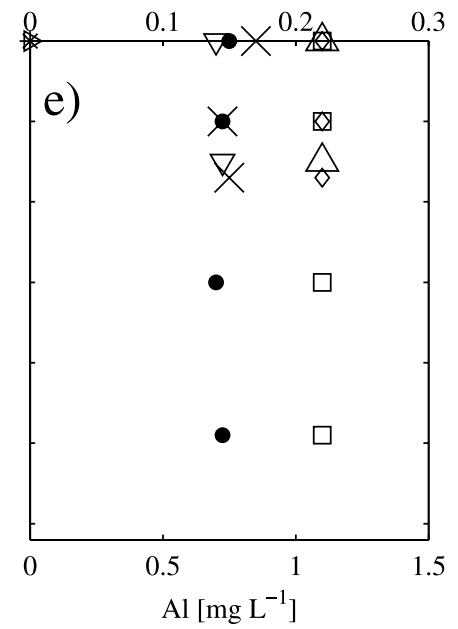

$\mathrm{Fe}\left[\mathrm{mg} \mathrm{L}^{-1}\right]$

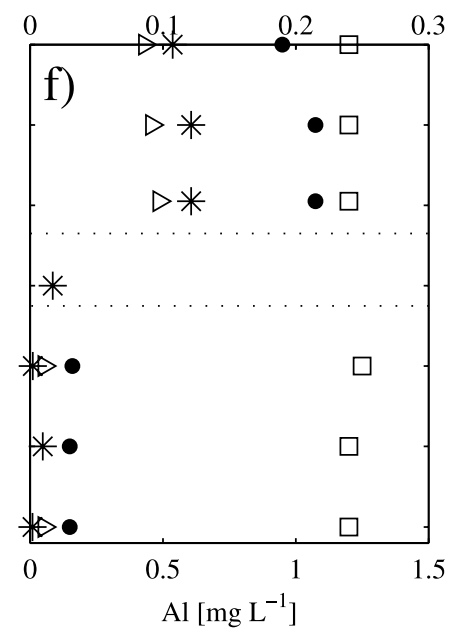

Figure 5 

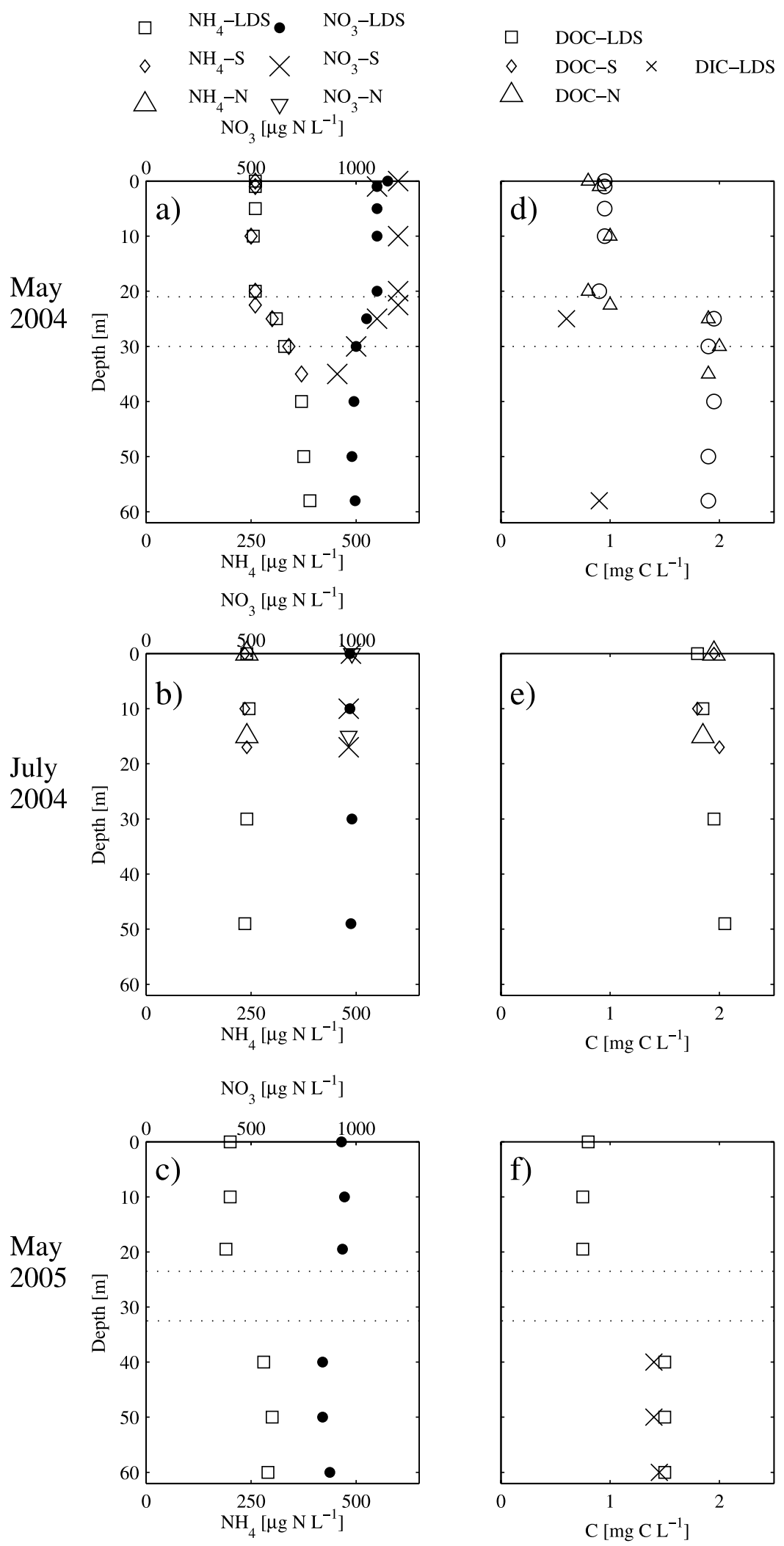

Figure 6. Water column concentrations profiles of $(\mathrm{a}-\mathrm{c}) \mathrm{NH}_{4}{ }^{+}$and $\mathrm{NO}_{3}{ }^{-}$and $(\mathrm{d}-\mathrm{f}) \mathrm{DOC}$ and DIC in May 2004, July 2004, and May 2005. The dashed lines indicate the location of the thermocline during stratification periods. Note that DIC was above the detection limit only during stratification, in or below the thermocline (see text), and in May 2004 was only measured at depths of 0,25 , and $58 \mathrm{~m}$. 


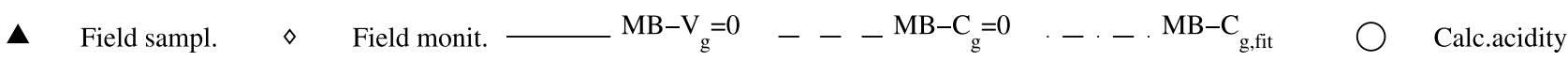

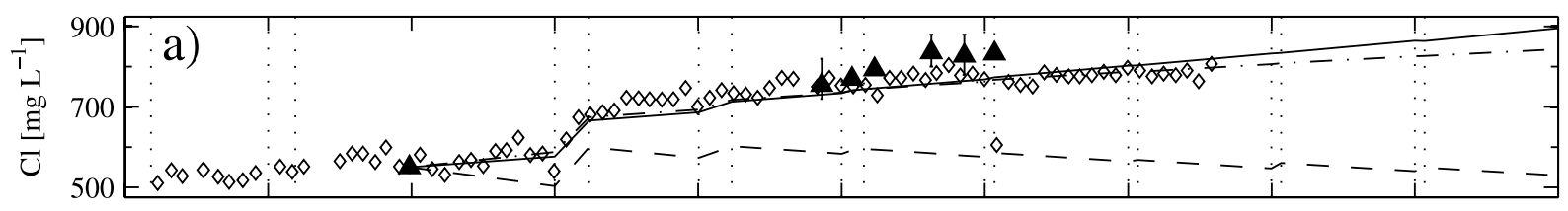
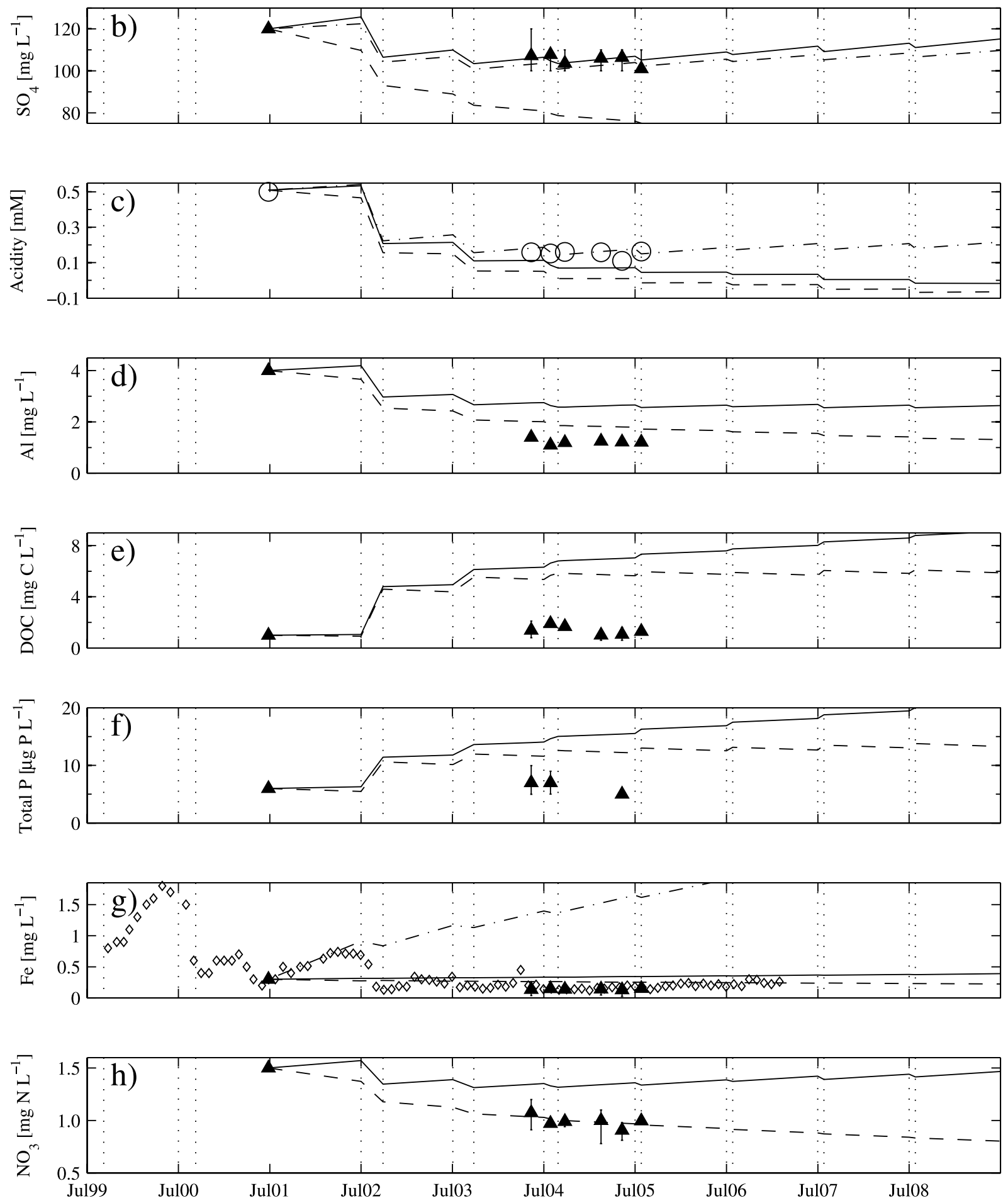

Figure 7 
gradual increase in $\mathrm{Cl}$ concentrations since this time was predominantly due to evapoconcentration.

[49] The mass balance calculations indicated that the major part of the decrease in $\mathrm{SO}_{4}^{2-}$ and acidity concentrations between 2001 and 2004-2005 could be explained by dilution by river water, or dilution and neutralization in the case of acidity, in both cases counteracting the effect of evapoconcentration. As for $\mathrm{Cl}$, the $\mathrm{SO}_{4}^{2-}$ mass balance reproduced the change in the $\mathrm{SO}_{4}^{2-}$ concentration with time in both the scenarios with no groundwater and by the scenario with the $2.2 \mathrm{GL}$ of groundwater throughflow with a calibrated concentration. However, for $\mathrm{SO}_{4}^{2-}$ the groundwater concentration required to reproduce the field observations was approximately $50 \%$ greater than the maximum concentration observed in the field (Table 1).

[50] For the acidity mass balance, even the scenario with no groundwater (that is, with maximum effect of evapoconcentration) underestimated the field observations, and in the scenario with groundwater inflow and calibrated concentration, the required $\mathrm{C}_{\mathrm{g} \text {,fit }}$ was at the upper end of the observed concentration range. This suggested that either with or without groundwater inflow, there is an acidity loading on the lake. Interestingly, the required acidity concentration in the assumed groundwater inflow $\left(\sim 60 \mathrm{mg} \mathrm{L}^{-1}\right)$ corresponds to $\sim 17 \mathrm{mg} \mathrm{L}^{-1} \mathrm{Fe}$ (II), which is within the range of $\mathrm{Fe}$ concentrations observed in the groundwater (Table 1). This loading may also be internal (see discussion below); these calculations do not allow for exclusion of either possibility. The acidity loading under the different groundwater scenarios was important for forward evolution of the lake acidity; specifically, the assumed acidity loading determined whether acidity in the lake remained constant or decreased with time (Figure 7c).

[51] Mass balances for organic carbon, phosphorus species and $\mathrm{Al}$ overestimated the observed lake concentrations in 2004-2005, even when assuming pure dilution by groundwater (i.e., $\mathrm{V}_{\mathrm{g}}=2.2 \mathrm{GL}, \mathrm{C}_{\mathrm{g}}=0$; Figures $7 \mathrm{~d}-7 \mathrm{f}$ ). These results clearly indicated that the lake was a sink for these species. If the groundwater Fe concentrations were calibrated to reproduce the observed increase in the lake concentration in 2001-2002, the lake was also a sink for Fe (Figure $7 \mathrm{~g}$ ); the required groundwater concentration was well within the range of observed Fe groundwater concentrations (Table 1). For $\mathrm{NO}_{3}^{-}$, the effect of river inflow plus groundwater dilution (i.e., $\mathrm{C}_{\mathrm{g}}=0$ ) closely reproduced the decrease in concentration observed in field (Figure $7 \mathrm{~h}$ ).

\section{Discussion}

[52] From inspection of the concentration depth profiles over an annual cycle in the lake and comparison of external mass balances with the field data, we begin to form a conceptual model for processes controlling concentrations in the lake. The lake was monomictic over the 2003-2006 period, with complete overturn in the winter and stable stratification during the summer. During stratification, biological or chemical oxygen demand was insufficient to result in anoxic conditions in the hypolimnion. As ammonium is generally rapidly oxidized to $\mathrm{NO}_{3}^{-}$in the presence of DO, the ammonium accumulation observed in the oxic hypolimnion of Lake Kepwari would be unexpected in a neutral water body, however, this phenomenon is commonly observed in acidic water bodies, and is attributed to inhibition of nitrification at lower $\mathrm{pH}$ [Schindler et al., 1991; Villaverde et al., 1997].

[53] For major conservative ions in solution, such as $\mathrm{Cl}$, the balance of in-/outflows and evapoconcentration appeared to be the major control on concentration evolution, as saturation index calculations indicated that most major ions in solution were not controlled by solubility equilibria at the conditions in the lake during this investigation. On the other hand, $\mathrm{Fe}$ and $\mathrm{Al}$ appeared to be in solubility equilibrium with mineral phases. While the acidity loading to pit lakes typically originates from iron sulfide oxidation, solubility equilibrium with $\mathrm{Al}$ and $\mathrm{Fe}(\mathrm{III})$ hydroxides (see equation (2)) is commonly reported to buffer the $\mathrm{pH}$ within pit lakes [e.g., Geller et al., 1998; Eary, 1999]; this would thus also appear to be the case in Lake Kepwari.

[54] In Lake Kepwari, water column acidity, predominantly in the form of dissolved Al, decreased after 2001 but was still present in the water column in 2004-2005 (Figure 7), indicating that the inflow of alkalinity with the river diversion has neutralized the acidity present in the lake in 2001 to a degree. However, alkalinity addition has been insufficient to overcome acidity originally present in the void when filling began. Furthermore, the conservative mass balances suggested that there was an additional acidity loading on the lake since 2001; an ongoing acidity loading is also consistent with the observed decrease in lake $\mathrm{pH}$ since the start of the project in 2004 (Figure 2).

[55] A possible source of acidity was a loading of Fe or $\mathrm{Al}$ on the lake (see equation (6)), for example in groundwater. Aluminum was not analyzed in the groundwater, however, high $\mathrm{Fe}$ concentrations, corresponding to up to $0.8 \mathrm{mM}$ of acidity, were observed in some groundwater wells (Table 1). Inclusion of iron-bearing groundwater in the mass balances was required to reproduce the observed increase in the Fe concentration in the lake in 2001-2002 (Figure 7), at which time the $\mathrm{pH}$ may have been sufficiently low (Figure 2) for Fe to exhibit conservative behavior. An alternative or additional possible source of Fe and acidity is ongoing oxidation of pyrite-bearing coal seams or waste rock exposed to the oxic water column along the lake boundaries and interior. Furthermore, deposits of mineral weathering products on pit walls and surrounding waste rock may have be dissolved as water levels rose in the lake.

Figure 7. Evolution of Lake Kepwari water quality and mass balance results for (a) $\mathrm{Cl}$, (b) $\mathrm{SO}_{4}{ }^{2-}$, (c) acidity, (d) $\mathrm{Al}$, (e) DOC, (f) Total $\mathrm{P},(\mathrm{g}) \mathrm{Fe}$, and (h) $\mathrm{NO}_{3}{ }^{-}$. Filled triangles ("Field sampl.") show the depth averaged field data values from this study from 2004 to 2005 (error bars indicate min-max values) and July 2001. Diversion periods are indicated by vertical dotted lines. Results of mass balance calculations are shown for scenarios of (1) no groundwater $\left(\mathrm{V}_{\mathrm{g}}=0\right.$; solid line), (2) groundwater throughflow $\left(\mathrm{V}_{\mathrm{g}}=2.2 \mathrm{GL}\right.$ ) with $\mathrm{C}_{\mathrm{g}}=0$, and (3) for $\mathrm{Cl}$, acidity, $\mathrm{SO}_{4}{ }^{2-}$, and $\mathrm{Fe}$, groundwater

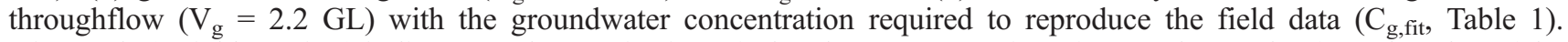
Diamonds ("Field monit.") indicate regular monitoring of $\mathrm{Cl}$ and Fe concentrations from grab samples from the edge of the lake (source: Wesfarmers Premier Coal). Circles indicate acidity as calculated from field data according to equation (6). 
The latter process has been well documented during flooding of underground mines [e.g., Younger, 2000] and would constitute a single, pulsed source as Lake Kepwari was filled, whereas the previously mentioned potential sources may be ongoing. As previously discussed, the current mass balance calculations and data do not allow exclusion of either internal or external loading.

[56] Irrespective of the source(s) of acidity, the forward mass balances indicated that the potential for the acidity in Lake Kepwari to decrease is sensitive to the acidity loading (Figure 7c). Furthermore, internal acidity sinks were not included in the mass balance calculation; if there were sinks in the lake, such as IAG, the magnitude of the acidity source(s) would be even greater. Ideally, IAG, together with any alkalinity inflow, would suffice to both neutralize the acidity present in the water column and maintain a natural buffering system against any ongoing acidity loading. As mentioned in the introduction, a possible alkalinity source is anaerobic, microbially mediated oxidation of organic matter in conjunction with the reduction of $\mathrm{NO}_{3}^{-}, \mathrm{Fe}(\mathrm{III})$ or $\mathrm{SO}_{4}^{2-}$ (equations (3)-(5)). However, this source of alkalinity has elsewhere been shown to be limited by the supply of organic carbon in pit lakes [e.g., Wendt-Potthoff et al., 2002; Frömmichen et al., 2003, 2004]. Sources and sinks of organic carbon in Lake Kepwari are thus likely to exert a strong influence on acidity balance and hence the long-term evolution of the lake $\mathrm{pH}$.

[57] Organic carbon concentrations increased throughout the lake from May to July 2004 (Figures 6d and 6e); the highest chlorophyll $a$ measurements were also recorded in July 2004, suggesting the increase was due to primary production. Primary production is typically one of the major internal sources of organic carbon in lakes; furthermore, IAG calculations on (circum neutral) lakes showed that productive lakes have the capacity to generate up to ten times more alkalinity than non-productive lakes [Koschorreck and Tittel, 2007]. High levels of primary productivity, albeit with reduced biodiversity, have been reported under highly acidic conditions, suggesting that acidity in itself is not a limiting factor in organic matter production [Blouin, 1989; Nixdorf et al., 1998]. However, while Lake Kepwari was eutrophic with respect to inorganic nitrogen, it was oligotrophic with respect to total $\mathrm{P}$, suggesting that primary production is limited by phosphorus availability [Wetzel, 2001] and is thus not likely to be a major contributor to the organic carbon pool in the lake. The low chlorophyll $a$ concentrations observed in Lake Kepwari, relative to other systems [Wetzel, 2001], also support this hypothesis.

[58] Limitation of primary productivity in Lake Kepwari may be indirectly exacerbated by the $\mathrm{pH}$ conditions in the lake, as under mildly acidic conditions the sorption of phosphorus to mineral surfaces is enhanced [e.g., Detenbeck and Brezonik, 1991]. Precipitation and sedimentation of Al and $\mathrm{Fe}$ (III) minerals out of the water column scavenges phosphorus from the water column; reductive dissolution of $\mathrm{Fe}(\mathrm{III})$ minerals (equation (4)) under anoxic conditions will lead to release of sorbed phosphorus, whereas Al minerals are not susceptible to this process [e.g., Kopacek et al., 2005]. Indeed, the subsequent sedimentation and sediment burial is so effective $\mathrm{Al}$ salts (or Fe, in oxygenated systems) are added to eutrophic water bodies to remove phosphorus and thereby limit primary production [e.g., Rydin et al.,
2000; Kopacek et al., 2005]. The mass balances indicated that Lake Kepwari was indeed a sink of phosphorus, as well as $\mathrm{Al}$ and $\mathrm{Fe}$ (Figure 7). Thus the phosphorus-mineral interaction at the intermediate $\mathrm{pH}$ in Lake Kepwari likely limits primary production, and hence the internal organic carbon supply for IAG, to a greater degree than in a circum neutral or highly acidic lake.

[59] As primary productivity and therefore organic carbon generation in the lake is constrained by phosphorus limitation, the slight increase in DOC concentration between May and July 2004 is likely to have been due to inflow of the river water with a relatively high organic carbon content (Table 1; note that even in the river, organic carbon is predominantly in dissolved form). Over longer periods organic carbon concentrations have decreased in the lake; overestimation of the 2004/2005 DOC concentrations in mass balance calculations (Figure 7e) indicates that the lake is a net sink for organic carbon. Comparison of DOC profiles from July 2004 and May 2005 (Figures 6e and 6f) suggested an organic carbon sink throughout the water column, with a greater sink in the epilimnion. Aerobic decomposition of DOC is suggested by the observed accumulation of DIC and $\mathrm{NH}_{4}^{+}$(Figure 6) and partial depletion of DO (Figure 4) below the thermocline. This process would also occur in the epilimnion, probably at a higher rate due to higher water temperature and greater oxygen availability.

[60] Removal of organic carbon from the water column is also enhanced under acidic conditions, as evidenced by the greater transparency typically observed in lakes in response to a decrease in $\mathrm{pH}$ [e.g., Schindler et al., 1991, 1997; Bukaveckas and Driscoll, 1991]. This phenomenon has been attributed removal of DOC from the water column by flocculation with $\mathrm{Al}$ and sedimentation [Effler et al., 1985]. Indeed, as for phosphorus, $\mathrm{Al}$ and Fe salts are used in process engineering applications to remove DOC [e.g., Kastl et al., 2004]. Flocculation and sedimentation of DOC in Lake Kepwari would imply enhanced organic carbon transport to sediments, which would have long-term benefits for IAG in the sediments. However, confirmation that this process is occurring in Lake Kepwari would require more detailed sampling and analysis of material sedimenting out of the water column.

[61] An additional organic carbon sink that may be enhanced at the $\mathrm{pH}$ conditions in Lake Kepwari is photooxidation. The rate of photooxidation has been shown to increase with decreasing $\mathrm{pH}$ and increasing availability of light, Fe, and DO [Zepp et al., 1992; Gao and Zepp, 1998; Gennings et al., 2001; Anesio and Graneli, 2003; Molot et al., 2005] and accelerated photochemical loss of DOC to DIC under the low $\mathrm{pH}, \mathrm{Fe}$-rich conditions in acidic pit lakes has previously been suggested to lead to limitation of IAG [Herzsprung et al., 1998]. Photooxidation of organic carbon may thus contribute to the greater DOC sink term in the epilimnion of Lake Kepwari.

[62] Photochemical reactions of Fe with organic carbon may also explain the elevated epilimnetic Fe concentration in Kepwari, $\sim 40 \%$ of which was in the form of $\mathrm{Fe}$ (II) (Figure 5), a trend observed in other acidic, oxic lakes [Collienne, 1983; Herzsprung et al., 1998]. In neutral waters, abiotic oxidation of Fe(II) by oxygen is rapid and hence the concentration of Fe(II) usually low [e.g., Sivan et al., 1998]; 
as $\mathrm{Fe}(\mathrm{III})$ is relatively insoluble, precipitation and sedimentation of $\mathrm{Fe}(\mathrm{OH})_{3}(\mathrm{~s})$ would lead to eventual removal of $\mathrm{Fe}$ from the water column. However, with decreasing $\mathrm{pH}$, the rate of $\mathrm{Fe}$ (II) oxidation decreases by orders of magnitude, unless mediated by acidophilic bacteria [Singer and Stumm, 1970]. Photoreduction-induced redox cycling back through the more soluble Fe(II) redox species, combined with a limited rate of $\mathrm{Fe}(\mathrm{II})$ oxidation, would allow the observed accumulation of $\mathrm{Fe}$ (II), and hence total dissolved Fe, in the epilimnion. Inflow of $\mathrm{Fe}(\mathrm{II})$-bearing groundwater, pyrite oxidation (equation (1)), or Fe(II) release from sediments (equation (4)) may also contribute to the observed Fe(II) profiles, if localized to the upper regions of the lake. Further quantification of fluxes due to specific processes is required to assess the relative dominance of the different sources and sinks of organic carbon and Fe, and hence the overall impact of each process on the water column acidity balance.

[63] If IAG is occurring in anoxic Lake Kepwari sediments, this process would also constitute a sink for organic carbon in the lake. Given the "ecological" (thermodynamic) redox sequence of electron donors for organic matter oxidation and the high $\mathrm{NO}_{3}^{-}$concentration in the lake, we would expect denitrification (equation (3)), with an associated decrease in $\mathrm{NO}_{3}^{-}$, organic carbon, and acidity. These components have indeed decreased since 2001 (Figure 7), however as discussed above, there are many possible alternative sinks for DOC in Lake Kepwari, and there are indications of at least one additional source of acidity, implying that these parameters cannot be used to track denitrification. For $\mathrm{NO}_{3}^{-}$, a conservative mass balance using high groundwater throughflow, with zero groundwater $\mathrm{NO}_{3}^{-}$ concentration, reproduced the observed $\mathrm{NO}_{3}^{-}$concentration decrease in the lake (Figure $7 \mathrm{~h}$ ). As the $\mathrm{NO}_{3}^{-}$concentrations observed in the groundwater were in fact low (Table 1), this would suggest that there was not a major sink of $\mathrm{NO}_{3}^{-}$in the lake. However, as for other species, the assumptions of high groundwater throughflow and concentrations based on limited groundwater sampling need further validation before we can exclude the possibility of internal processes, such as denitrification, affecting lake $\mathrm{NO}_{3}^{-}$concentrations. Quantification of external loading for all species, and/or well-constrained internal sink/source terms, is thus crucial for both testing the conceptual model of dominant processes controlling lake acidity and $\mathrm{pH}$ and for forward water quality predictions.

\section{Conclusions}

[64] This study has highlighted the need for integrated assessment of geochemical, physical, and biological processes in acidic pit lakes, as well as external mass balances, in order to assess evolution of pit lake water quality. In Lake Kepwari, the main controls on concentrations of major, conservative ions are the balance of in-/outflows and evapoconcentration. Acidity in the water column is predominantly in the form of $\mathrm{Al}$, suggesting that solubility equilibrium control of $\mathrm{Al}$ is also controlling the $\mathrm{pH}$ in the lake. Water column acidity has decreased over a number of years, and the lake is a net sink for organic carbon, however, the decrease in acidity can mainly be explained by inflow of river alkalinity, suggesting that either the organic carbon is not being converted to alkalinity on a significant scale, or the effect is masked by additional sources of acidity, which may include Fe-rich groundwater. The acidic conditions in the lake likely reinforce organic carbon limitation on IAG, through enhanced photoreactions of organic carbon with $\mathrm{Fe}$ and phosphorus-limitation on primary production. Nitrogen cycling is also disrupted by the low $\mathrm{pH}$, as has been observed in acidic systems elsewhere.

[65] The simple external mass balance approach applied here has allowed us to explore the degree of internal interactions between acidity and organic carbon, within the limits of the available data. However, once components enter a lake, the water quality is influenced by complex internal feedbacks between factors such as carbon and nutrient sources and sinks in the water column and sediments, mineral equilibria, redox reactions of oxygen and $\mathrm{Fe}$, and stratification. External mass balances will quickly prove insufficient to predict evolution of water quality, particularly if in-lake primary production were to become a significant source of organic carbon, for example in response to remediation measure such as nutrient addition. Given the interdependence of carbon and nutrient cycles, geochemistry, and physical limnology, and the possibility of multiple sinks and sources for many key species, such as organic carbon and Fe, identification of dominant processes and forward prediction would be assisted by evaluation with a numerical model that quantifies all of these processes and feedbacks. Such a model would also inform the spatial and temporal design of future field campaigns and laboratory experiments to test and validate our process understanding. The quantitative study of integrated controls on pit lake water quality, for which long-term, well-constrained data sets are desperately needed, will also provide insight into the evolution of other systems where acidity may be overcome by organic carbon-driven processes, such as water bodies impacted by atmospheric acid deposition [Dillon et al., 1984] or drainage from acid sulfate soils [Burton et al., 2006], and the development of primordial lakes and wetlands [Benison et al., 1998].

[66] Acknowledgments. The authors would like to thank Greg Attwater, Geoff Wake, Rene Frömmichen, Peter Riley, Alice Turnbull, Tristan Derham, Manuela Susanto, and many others for assistance with the collection of field data. This project was funded by the Western Australian Centre for Excellence in Sustainable Mine Lakes, and by Australian Research Council Project LP0454252. This paper is School of Environmental Systems Engineering Report SESE025-US.

\section{References}

Anesio, A. M., and W. Graneli (2003), Increased photoreactivity of DOC by acidification: Implications for the carbon cycle in humic lakes, Limnol. Oceanogr., 48, 735-744.

APHA (1992), Standard Methods for the Examination of Water and Wastewater, American Public Health Association, Washington, D. C.

Ball, J. W., and D. K. Nordstrom (1991), User's manual for WATEQ4F, with revised thermodynamic database and test cases for calculating speciation of major, trace and redox elements in natural waters, Open-File Report 91-183, 189 pp., U.S. Geological Survey, Denver, Colo. (Revised and reprinted August 1992.)

Benison, K. C., R. H. Goldstein, B. Wopenka, R. C. Burruss, and J. D. Pasteris (1998), Extremely acid Permian lakes and ground waters in North America, Nature, 392, 911-914.

Blodau, C. (2006), A review of acidity generation and consumption in acidic coal mine lakes and their watersheds, Sci. Total Environ., 369, $307-332$.

Blouin, A. C. (1989), Patterns of plankton species, $\mathrm{pH}$ and associated water chemistry in Nova Scotia lakes, Water Air Soil Pollut., 46, 343-358.

Bukaveckas, P. A., and C. T. Driscoll (1991), Effects of whole-lake base addition on the optical-properties of 3 clearwater acidic lakes, Can. J. Fish. Aquat. Sci., 48, 1030-1040. 
Burton, E. D., R. T. Bush, and L. A. Sullivan (2006), Sedimentary iron geochemistry in acidic waterways associated with coastal lowland acid sulfate soils, Geochim. Cosmochim. Acta, 70, 5455-5468.

Collienne, R. H. (1983), Photoreduction of iron in the epilimnion of acidic lakes, Limnol. Oceanogr., 28, 83-100.

Davis, A., and D. Ashenberg (1989), The aqueous geochemistry of the Berkeley Pit, Butte, Montana, USA, Appl. Geochem., 4, 23-36.

Detenbeck, N. E., and P. L. Brezonik (1991), Phosphorus sorption by sediments from a soft-water seepage lake. 2: Effects of $\mathrm{pH}$ and sediment composition, Environ. Sci. Technol., 25, 403-409.

Dillon, P. J., N. D. Yan, and H. H. Harvey (1984), Acidic depositionEffects on aquatic ecosystems, CRC Crit. Rev. Environ. Control, 13, $167-194$.

Doupé, R. G., and A. J. Lymbery (2005), Environmental risks associated with beneficial end uses of mine lakes in southwestern Australia, Mine Water Environ., 24, 134-138.

Drever, J. I. (1997), The Geochemistry of Natural Waters: Surface and Groundwater Environments, 3rd ed., 436 pp., Prentice-Hall, Inc., New Jersey.

Eary, L. E. (1999), Geochemical and equilibrium trends in mine pit lakes, Appl. Geochem., 14, 963-987.

Effler, S. W., G. C. Schafran, and C. T. Driscoll (1985), Partitioning light attenuation in an acidic lake, Can. J. Fish. Aquat. Sci., 42, 1707-1711.

Frömmichen, R., S. Kellner, and K. Friese (2003), Sediment conditioning with organic and/or inorganic carbon sources as a first step in alkalinity generation of acid mine pit lake water ( $\mathrm{pH} 2-3)$, Environ. Sci. Technol., $37,1414-1421$.

Frömmichen, R., K. Wendt-Potthoff, K. Friese, and R. Fischer (2004), Microcosm studies for neutralization of hypolimnic acid mine lake water (pH 2.6), Environ. Sci. Technol., 38, 1877-1887.

Gao, H. Z., and R. G. Zepp (1998), Factors influencing photoreactions of dissolved organic matter in a coastal river of the southeastern United States, Environ. Sci. Technol., 32, 2940-2946.

Geller, W., H. Klapper, and W. Salomons (Eds.) (1998), Acidic Mining Lakes: Acid Mine Drainage, Limnology and Reclamation, Springer, New York.

Gennings, C., L. A. Molot, and P. J. Dillon (2001), Enhanced photochemical loss of organic carbon in acidic waters, Biogeochemistry, 52, 339354.

Herzsprung, P., K. Friese, G. Packroff, M. Schimmele, K. Wendt-Potthoff, and M. Winkler (1998), Vertical and annual distribution of ferric and ferrous iron in acidic mining lakes, Acta Hydrochim. Hydrobiol., 26, 253-262.

Kastl, G., A. Sathasivan, I. Fisher, and J. Van Leewen (2004), Modelling DOC removal by enhanced coagulation, J. Am. Water Works Assoc., 96, $79-89$.

Kelly, C. A., J. W. M. Rudd, R. B. Cook, and D. W. Schindler (1982), The potential importance of bacterial processes in regulating rate of lake acidification, Limnol. Oceanogr., 27, 868-882.

Kirby, C. S., and C. A. Cravotta (2005), Net alkalinity and net acidity. 1: Theoretical considerations, Appl. Geochem., 20, 1920-1940.

Kopacek, J., J. Borovec, J. Hejzlar, K. U. Ulrich, S. A. Norton, and A. Amirbahman (2005), Aluminum control of phosphorus sorption by lake sediments, Environ. Sci. Technol., 39, 8784-8789.

Koschorreck, M., and J. Tittel (2007), Natural alkalinity generation in neutral lakes affected by acid mine drainage, J. Environ. Qual., 36, $1163-1171$.

Miller, G. C., W. B. Lyons, and A. Davis (1996), Understanding the water quality of pit lakes, Environ. Sci. Technol., 30, 118A-123A.

Molot, L. A., J. J. Hudson, P. J. Dillon, and S. A. Miller (2005), Effect of $\mathrm{pH}$ on photo-oxidation of dissolved organic carbon by hydroxyl radicals in a coloured, softwater stream, Aquat. Sci., 67, 189-195.

Nixdorf, B., U. Mischke, and D. Lessmann (1998), Chrysophytes and chlamydomonads: Pioneer colonists in extremely acidic mining lakes $(\mathrm{pH}<3)$ in Lusatia (Germany), Hydrobiologia, 370, 315-327.
Nordstrom, D. K., and C. N. Alpers (1999), Geochemistry of acid mine waters, in The Environmental Geochemistry of Mineral Deposits, Reviews in Economic Geology, vol. 6A, edited by G. S. Plumlee and M. J. Logsdon, pp. 133-160, Society of Economic Geologists, Chelsea, Mo.

Nordstrom, D. K., E. A. Jenne, and J. W. Ball (1979), Redox equilibria of iron in acid mine waters, in Chemical Modeling in Aqueous Systems, ACS Symposium Series, vol. 93, edited by E. A. Jenne, pp. 51-77, American Chemical Society, Columbus, Ohio.

Parkhurst, D. L., and C. A. J. Appelo (1999), User's guide to PHREEQC (version 2)-A computer program for speciation, batch-reaction, onedimensional transport, and inverse geochemical calculations, WaterResources Investigations Report 99-4259, 312 pp., U.S. Geological Survey, Denver, Colo.

Pellicori, D. A., C. H. Gammons, and S. R. Poulson (2005), Geochemistry and stable isotope composition of the Berkeley pit lake and surrounding mine waters, Butte, Montana, Appl. Geochem., 20, 2116-2137.

Rydin, E., B. Huser, and E. B. Welch (2000), Amount of phosphorus inactivated by alum treatments in Washington lakes, Limnol. Oceanogr., $45,226-230$.

Schindler, D. W., et al. (1991), Comparisons between experimentallyacidified and atmospherically-acidified lakes during stress and recovery, Proc. R. Soc. Edinburgh B, 97, 193-226.

Schindler, D. W., P. J. Curtis, S. E. Bayley, B. R. Parker, K. G. Beaty, and M. P. Stainton (1997), Climate-induced changes in the dissolved organic carbon budgets of boreal lakes, Biogeochemistry, 36, 9-28.

Singer, P. C., and W. Stumm (1970), Acidic mine drainage. Rate-determining step, Science, 167, 1121-1123.

Sivan, O., Y. Erel, D. Mandler, and A. Nishri (1998), The dynamic redox chemistry of iron in the epilimnion of Lake Kinneret (Sea of Galilee), Geochim. Cosmochim. Acta, 62, 565-576.

Stevens, C. L., T. S. R. Fisher, and G. A. Lawrence (2005), Turbulent layering beneath the pycnocline in a strongly stratified pit lake, Limnol. Oceanogr., 50, 197-206.

Stumm, W., and J. J. Morgan (1996), Aquatic Chemistry: Chemical Equilibria and Rates in Natural Waters, 3rd ed., 1022 pp., John Wiley \& Sons, Inc., New York.

Totsche, O., R. Pöthig, W. Uhlmann, H. Büttcher, and C. E. W. Steinberg (2003), Buffering mechanisms in acidic mining lakes-A model-based analysis, Aquat. Geochem., 9, 343-359.

Varma, S. (2002), Hydrogeology and groundwater resources of the Collie Basin, Western Australia, Report HG5, Water and Rivers Commission of Western Australia, Perth, Australia.

Villaverde, S., P. A. Garciaencina, and F. Fdzpolanco (1997), Influence of $\mathrm{pH}$ over nitrifying biofilm activity in submerged biofilters, Water Res., $31,1180-1186$.

Wendt-Potthoff, K., R. Frömmichen, P. Herzsprung, and M. Koschorreck (2002), Microbial Fe(III) reduction in acidic mining lake sediments after addition of an organic substrate and lime, Water Air Soil Pollut.: Focus, $00,1-16$.

Wetzel, R. G. (2001), Limnology: Lake and River Ecosystems, 3rd ed., 1006 pp., Academic Press, San Diego.

Younger, P. L. (2000), Predicting temporal changes in total iron concentrations in groundwaters flowing from abandoned deep mines: A first approximation, J. Contam. Hydrol., 44, 47-69.

Yu, J. Y., M. Park, and J. Kim (2002), Solubilities of synthetic schwertmannite and ferrihydrite, Geochem. J., 36, 119-132.

Zepp, R. G., B. C. Faust, and J. Hoigne (1992), Hydroxyl radical formation in aqueous reactions ( $\mathrm{pH} \mathrm{3-8)}$ of Iron(II) with hydrogen-peroxide-The photo-fenton reaction, Environ. Sci. Technol., 26, 313-319.

G. N. Ivey, C. E. Oldham, and S. U. Salmon, School of Environmental Systems Engineering, University of Western Australia, 35 Stirling Highway, Nedlands, WA 6009, Australia. (ursula.salmon@uwa.edu.au) 